\title{
2004s-55
}

\section{The Determinants of Credit Default Swap Premia}

\author{
Jan Ericsson, Kris Jacobs, \\ Rodolfo A. Oviedo
}

Série Scientifique
Scientific Series

Montréal

Novembre 2004

(C) 2004 Jan Ericsson, Kris Jacobs, Rodolfo A. Oviedo. Tous droits réservés. All rights reserved. Reproduction partielle permise avec citation du document source, incluant la notice (C)

Short sections may be quoted without explicit permission, if full credit, including (C) notice, is given to the source.
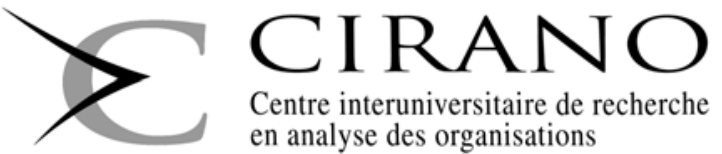

Centre interuniversitaire de recherche en analyse des organisations 


\section{CIRANO}

Le CIRANO est un organisme sans but lucratif constitué en vertu de la Loi des compagnies du Québec. Le financement de son infrastructure et de ses activités de recherche provient des cotisations de ses organisations-membres, d'une subvention d'infrastructure du Ministère du Développement économique et régional et de la Recherche, de même que des subventions et mandats obtenus par ses équipes de recherche.

CIRANO is a private non-profit organization incorporated under the Québec Companies Act. Its infrastructure and research activities are funded through fees paid by member organizations, an infrastructure grant from the Ministère du Développement économique et régional et de la Recherche, and grants and research mandates obtained by its research teams.

PARTENAIRE MAJEUR

$$
\text { Les organisations-partenaires / The Partner Organizations }
$$

. Ministère du Développement économique et régional et de la Recherche [MDERR]

PARTENAIRES

. Alcan inc.

. Axa Canada

. Banque du Canada

. Banque Laurentienne du Canada

. Banque Nationale du Canada

. Banque Royale du Canada

. Bell Canada

. BMO Groupe Financier

. Bombardier

. Bourse de Montréal

. Caisse de dépôt et placement du Québec

. Développement des ressources humaines Canada [DRHC]

. Fédération des caisses Desjardins du Québec

. GazMétro

. Hydro-Québec

. Industrie Canada

. Ministère des Finances du Québec

. Norshield Asset Management (Canada) Ltd.

. Pratt \& Whitney Canada Inc.

. Raymond Chabot Grant Thornton

. Ville de Montréal

. École Polytechnique de Montréal

. HEC Montréal

. Université Concordia

. Université de Montréal

. Université du Québec

. Université du Québec à Montréal

. Université Laval

. Université McGill

. Université de Sherbrooke

Associe A :

. Institut de Finance Mathématique de Montréal (IFM²)

. Laboratoires universitaires Bell Canada

. Réseau de calcul et de modélisation mathématique $\left[\mathrm{RCM}^{2}\right]$

. Réseau de centres d'excellence MITACS (Les mathématiques des technologies de l'information et des systèmes complexes)

Les cahiers de la série scientifique (CS) visent à rendre accessibles des résultats de recherche effectuée au CIRANO afin de susciter échanges et commentaires. Ces cahiers sont écrits dans le style des publications scientifiques. Les idées et les opinions émises sont sous l'unique responsabilité des auteurs et ne représentent pas nécessairement les positions du CIRANO ou de ses partenaires.

This paper presents research carried out at CIRANO and aims at encouraging discussion and comment. The observations and viewpoints expressed are the sole responsibility of the authors. They do not necessarily represent positions of CIRANO or its partners. 


\title{
The Determinants of Credit Default Swap Premia*
}

\author{
Jan Ericsson ${ }^{\dagger}$, Kris Jacobs ${ }^{*}$, Rodolfo A. Oviedo ${ }^{\S}$
}

\begin{abstract}
Résumé / Abstract
En utilisant une nouvelle base de données de credit default swaps, nous étudions les relations entre les déterminants théoriques du risque de défaut et la prime actuelle du marché en utilisant la régression linéaire. Ces déterminants théoriques sont le niveau d'endettement de la firme, la volatilité et le taux d'intérêt sans risque. Nous trouvons que les coefficients estimés pour ces variables sont en accord avec la théorie et que les estimations sont fortement significatives aussi bien statistiquement qu'économiquement. Le pouvoir explicatif de ces variables théoriques sur le niveau de la prime du default swap est d'environ $60 \%$. Le pouvoir explicatif sur les différences de prime est de $23 \%$.La volatilité et le niveau d'endettement en eux-mêmes ont aussi un pouvoir explicatif substantiel pour la prime du credit default swap. Une analyse en composantes principales des résidus et de la prime montre qu'il n'y a pratiquement aucune trace d'un facteur commun résiduel et suggère également que les variables théoriques expliquent une part significative de la variance des données. Nous concluons donc que le niveau d'endettement, la volatilité et le taux sans risque sont d'importants déterminants de la prime des credit default swap, comme prédit par la théorie.
\end{abstract}

Mots clés : credit default swap, risque de crédit, modèle structurel niveau d'endettement, volatilité

Using a new dataset of bid and offer quotes for credit default swaps, we investigate the relationship between theoretical determinants of default risk and actual market premia using linear regression. These theoretical determinants are firm leverage, volatility and the riskless interest rate. We find that estimated coefficients for these variables are consistent with theory and that the estimates are highly significant both statistically and economically. The explanatory power of the theoretical variables for levels of default swap premia is approximately $60 \%$. The explanatory power for the differences in the premia is approximately 23\%. Volatility and leverage by themselves also have substantial explanatory power for credit default swap premia. A principal component analysis of the residuals and the premia shows that there is only weak evidence for a residual common factor and also suggests that the theoretical variables explain a significant amount of the variation in the data. We therefore conclude that leverage, volatility and the riskfree rate are important determinants of credit default swap premia, as predicted by theory.

Keywords: credit default swap; credit risk; structural model; leverage; volatility.

Codes JEL : G12

\footnotetext{
* Ericsson would like to thank FCAR, IFM2 for financial support and SIFR for making the default swap data available to us. Jacobs is grateful for financial support from FCAR, IFM2 and SSHRC. Oviedo-Helfenberger was supported in part by a grant of IFM2. Any remaining inadequacies are ours alone.

${ }^{\dagger}$ Research affiliate of SIFR. Address for correspondence: Faculty of Management, McGill University, 1001 Sherbrooke Street West, Montreal, Canada H3A 1G5; Tel: (514) 398-3186; Fax: (514) 398-3876; E-mail: jan.ericsson@mcgill.ca.

$¥$ CIRANO and Department of Finance, Faculty of Management, McGill University. $\S$ Faculty of Management, McGill University.
} 


\section{Introduction}

A credit derivative is a contingent claim that allows the trading of default risk separately from other sources of uncertainty. From being a fledgling market in the mid nineties, credit derivative markets have grown tremendously over the last few years. The market exceeded 2 trillion dollars in outstanding notional principal in 2002, and it is expected to double in size by the end of 2004. The most standard contract is the single-name credit default swap (CDS) which accounts for roughly half of the trading activity. ${ }^{1}$ This instrument is essentially an insurance contract against the default of an underlying entity. Compensation is paid if a credit event occurs while in return the buyer of protection makes regular payments based on the swap premium.

Little empirical work has been done on credit derivative markets. ${ }^{2}$ Notable exceptions include Houweling and Vorst (2005), Hull, Predescu, and White (2004) and Longstaff, Mithal, and Neis (2004). Houweling and Vorst (2005) implement a set of simple reduced form models on market CDS quotes and corporate bond quotes. The paper focuses on the pricing performance of the model and the choice of benchmark yield curve. Hull, Predescu, and White (2004) analyze the impact of rating announcements on the pricing of CDSs. Longstaff, Mithal, and Neis (2004) and Blanco, Brennan, and Marsh (2003) study the relative pricing of corporate bonds and default swaps.

In the last decade, a more substantial body of empirical work has emerged on other credit sensitive instruments, in particular corporate bonds. This work can be categorized according to the theoretical framework it relies on. One popular approach is to use what are known as reduced form models. ${ }^{3}$ These models exogenously postulate the dynamics of default probabilities and use market data to recover the parameters needed to value credit sensitive claims. ${ }^{4}$ While these models have been shown to be versatile in practical applications, they

\footnotetext{
${ }^{1}$ These statistics and forecasts are based on publications by the British Bankers' Association . A very similar picture emerges from our dataset. Although it includes some transactions that date back to 1995, the number of quotes is negligible until the turn of the century. Subsequently the market experienced explosive growth (see Figure 1).

${ }^{2}$ Theoretical work includes Das (1995), Hull and White (2000) and Das and Sundaram (1998).

${ }^{3}$ See Jarrow and Turnbull (1995) and Duffie and Singleton (1999) for early work on this topic. Useful surveys can be found in Lando (1997) and Duffie and Singleton (2003).

${ }^{4}$ Empirical papers using reduced form models to value credit risky bonds include Bakshi, Madan, and Zhang (2001), Driessen (2004), Duffee (1999), Duffie and Lando (2000), Duffie, Pedersen, and Singleton
} 
remain relatively silent on the theoretical determinants of the prices of defaultable securities.

An alternative approach, commonly referred to as the structural approach, is to rely on models that have evolved following Black and Scholes (1973) and Merton (1974). This approach links the prices of credit risky instruments directly to the economic determinants of financial distress and loss given default. ${ }^{5}$ In particular, these models imply that the main determinants of the likelihood and severity of default are financial leverage, volatility and the risk free term structure. These models have been plagued by poor performance in empirical studies. ${ }^{6}$ Perhaps as a result of the difficulty of implementing structural models in practice, a more direct approach was taken by Collin-Dufresne, Goldstein, and Martin (2001) (CGM), who use the structural approach to identify the theoretical determinants of corporate bond credit spreads. These variables are then used as explanatory variables in regressions for changes in corporate credit spreads, rather than inputs to a particular structural model. CGM conclude that the explanatory power of the theoretical variables is modest, and that a significant part of the residuals are driven by a common systematic factor which is not captured by the theoretical variables. Campbell and Taksler (2003) (CT) perform a similar analysis but use regressions for levels of the corporate bond spread. They conclude that firm specific equity volatility is an important determinant of the corporate bond spread and that the economic effects of volatility are large. Cremers, Driessen, Maenhout, and Weinbaum (2004) (CDMW) confirm this result, and argue that option-based volatility contains information useful for this type of analysis that is different from historical volatility.

Our study is intimately related to these papers. Although our focus is also on credit risk, an important distinction is that we study very different data - default swap premia rather than corporate bond yield spreads. Using default swaps rather than bonds has at least two important advantages.

First, default swap premia, while economically comparable to bond yield spreads, do not require the specification of a benchmark risk free yield curve - they are already "spreads". (2003) and Elton, Gruber, Agrawal, and Mann (2001).

${ }^{5}$ Important examples include Black and Cox (1976), Collin-Dufresne and Goldstein (2001), Geske (1977), Kim, Ramaswamy, and Sundaresan (1993), Leland (1994), Leland and Toft (1996), Longstaff and Schwartz (1995) and Nielsen, Saa-Requejo, and Santa-Clara (1993).

${ }^{6}$ See in particular Jones, Mason, and Rosenfeld (1984), Jones, Mason, and Rosenfeld (1985), Lyden and Saranati (2000) and Ogden (1987). More recently Eom, Helwege, and Huang (2004) have documented the difficulty of implementing these models. 
Thus we avoid any added noise arising from a misspecified model of the risk free yield curve. The choice of the risk free yield curve includes the choice of a reference risk free asset, which can be problematic (see Houweling and Vorst (2005)), but also the choice of a framework to remove coupon effects.

Second, default swap premia may reflect changes in credit risk more accurately and quickly than corporate bond yield spreads. Blanco, Brennan, and Marsh (2003) provide evidence that changes in the credit quality of the underlying name are likely to be reflected more quickly in the swap premium than in the bond yield spread. Also, if there are other important non-default components in bond spreads, their variation will obscure the impact of changes in credit quality. ${ }^{7}$

Like CGM, CT and CDMW, we carry out linear regression analysis on the relationship between default swap premia and key variables suggested by economic theory. Our benchmark results focus on financial leverage, firm specific volatility and the risk free rate. We run regressions on changes in premia as well as for the levels of the premia. We find that the estimated coefficients for the three variables are consistent with theory and that the estimates are highly significant both statistically and economically. The size of the effects is intuitively plausible. This is true both for regressions in levels and differences. Interestingly, we find a negative correlation between CDS premia and the risk free rate. A similar correlation has been documented for bond yield spreads by Longstaff and Schwartz (1995) and Duffee (1998). Presently, no consensus prevails as to the economic reasoning behind this stylized fact. Our results are consistent with the implication of structural models that an increase in the risk free rate will decrease risk-adjusted default probabilities.

The amount of the variation in swap premia explained by the difference regressions is higher than in existing work on corporate bond spreads. When we consider regressions in levels, explanatory power is quite high with R-squares ranging from $50 \%$ to $75 \%$. Thus variables drawn from economic theory are clearly important in explaining the pricing of this particular type of credit-sensitive instrument. This finding is reinforced by an analysis of

\footnotetext{
${ }^{7}$ Fisher (1959), Houweling, Mentink, and Vorst (2004), Longstaff, Mithal, and Neis (2004) and Perraudin and Taylor (2002) document the existence of an illiquidity component in bond yield spreads. In addition, Elton, Gruber, Agrawal, and Mann (2001) suggest that both the differential taxation of corporate and government bonds as well as compensation for systematic risk will impact bond spreads over and above the size of expected losses given default.
} 
the regression residuals, which shows that the evidence for a remaining common component is weaker than in the work of CGM on corporate bond data. We argue however that a comparison of our results with empirical results on corporate bond spreads should be interpreted cautiously. One reason is that the particular maturity structure of the CDS data is likely to influence our conclusions on the explanatory power of the results.

The paper proceeds as follows. In the next section, we lay out our analytical framework. In particular, we discuss the determinants of default swap premia suggested by existing theory and then present our regression equations. In section 3, we present and discuss our empirical results. Section 4 concludes.

\section{Analytical Framework}

\subsection{The Theoretical Determinants of Credit Default Swap premia}

There are two different approaches to modeling credit sensitive financial instruments. One approach is due to Merton (1974) and relies on a theoretical approach that explicitly relates the credit event to the value of the firm's assets. The firm is assumed to default on its obligations when the firm value falls below some threshold. These types of models are called structural models because the link with economic fundamentals is explicit. They can be used to price credit sensitive securities such as corporate bonds as well as credit default swaps. The second approach is more recent and finds its origins in the modeling of the risk free term structure. This approach is referred to as the reduced form approach because the relationship with underlying economic variables such as the firm value is not explicitly modeled.

This paper analyzes CDS premia from the perspective of structural form models. Following Merton's (1974) pathbreaking work, the basic structural model has been extended in different ways. ${ }^{8}$ While these models typically focus on the importance of additional theoretical variables, or change the precise functional dependence of default on existing theoretical

\footnotetext{
${ }^{8}$ See Black and Cox (1976), Geske (1977), Fischer, Heinkel, and Zechner (1989), Kim, Ramaswamy, and Sundaresan (1993), Nielsen, Saa-Requejo, and Santa-Clara (1993), Leland (1994), Longstaff and Schwartz (1995), Anderson and Sundaresan (1996), Leland and Toft (1996), Mella-Barral and Perraudin (1997), Zhou (1997), Leland (1998), Mella-Barral (1999), Duffie and Lando (2000), Collin-Dufresne and Goldstein (2001), François and Morellec (2004).
} 
variables, they all have in common that default and therefore the value of the default sensitive security depends on a number of determinants that are central to the Merton (1974) approach. First, leverage is central to all these models: ceteris paribus, the more levered the firm, the higher the probability of default. Second, the volatility of the underlying assets is an essential determinant of the value of the default sensitive security because the latter is equivalent to a credit risk free security and a short put. Volatility influences the value of the put option. Third, the level of the riskless rate also impacts the value of the option. Although the correlation between the risk free rate and the bond spread is strictly not part of Merton's (1974) analysis which relies on a constant interest rate, the framework does predict a negative relationship between these two variables. The reason is that the risk free rate determines the risk adjusted drift of firm value and thus an increase in this variable will tend to decrease risk adjusted default probabilities and also spreads. The same result has been shown in models where the dynamics of the risk free rate have been modelled explicitly. ${ }^{9}$

Rather than carrying out a full structural estimation of any given model or set of such, we rely on what these models together suggest are the main determinants of credit risk. We use these variables in simple linear regressions of default swap premia on the suggested factors. Note that although structural models have almost exclusively been used to value corporate bonds, the implied relationship between the theoretical variables and default swap premia is the same. This can be understood by considering the similarity between the payoffs of the two types of financial instruments. Bonds pay regular coupons and principal cash flows until default occurs. At that time, the bond will be worth a fraction of its original principal amount. ${ }^{10}$ The seller of default insurance through a CDS (analogous to the holder of the bond) receives regular payments (approximately the coupon rate on the bond minus the risk free rate) until default occurs, when he makes a payment equivalent to the loss in market value of the underlying bond - thus incurring the same loss as the holder of the bond. ${ }^{11}$

\footnotetext{
${ }^{9}$ See e.g. Longstaff and Schwartz (1995) and Collin-Dufresne and Goldstein (2001).

${ }^{10}$ Models differ in their exact technical treatment of this payment but this is without implications for the differences between bonds and default swaps.

${ }^{11}$ In practice, the settlement in the event of default may be made either in cash or in kind. If made in cash, a third party typically determines the post credit event market value of the reference obligation according to a predetermined formula and the payment made will be the original principal minus this value. If the settlement is in kind, the buyer of insurance will put the bond to the seller at par. In some cases, there may be a certain amount of flexibility for the buyer as to which bond can be delivered, much like for government
} 
Thus in terms of the sequence of cash flows and the impact of default, bonds and CDSs are very similar and structural model variables will have the same impact on the values of both securities. $^{12}$

In what follows, we will study the link between theoretically motivated determinants of default risk and market data on CDS premia using simple linear regression methods. In doing so, we closely parallel the approach taken by CT, CGM and CDMW using corporate bond data.

\subsection{Regressions}

According to theory, the premia on credit default swaps should be determined by the amount of leverage incurred by the underlying firm, the volatility of the underlying assets and the riskless spot rate. We denote the leverage of firm $i$ at time $t$ as $l e v_{i, t}$ and the volatility as $v_{i, t}$. We define the riskfree rate variable to be the 10 -year yield, denoted as $r_{t}^{10}$. This choice is motivated as follows. Theoretical models tend to be based on the dynamics of the instantaneous risk free rate, which is unobservable. A number of empirical studies have demonstrated that this unobservable short rate can be thought of as being determined by a number of factors, one of which is the yield on long-maturity bonds. In the interest of parsimony in the empirical presentation of the results, we therefore focus exclusively on this one proxy for the riskless spot rate in our base case regression results. The robustness of our findings with respect to a different choice of factor or the inclusion of additional factors is discussed in detail in Section 3.3.

The regression suggested by theory consists therefore of regressing the CDS premium, denoted by $S_{i, t}$, on these three variables. We also add a constant to this regression which yields

$$
S_{i, t}=\alpha_{i}^{l}+\beta_{i}^{l} l e v_{i, t}+\beta_{i}^{v} v_{i, t}+\beta_{i}^{r} r_{t}^{10}+\varepsilon_{i, t}
$$

bond futures contracts.

${ }^{12}$ In fact, in the absence of counterparty risk and market frictions, it can be shown that a CDS on a floating rate bond originally issued at par can be synthesized by an offsetting portfolio of this floater and an otherwise identical credit risk free floater. The net cash flows of this portfolio must equal those of the CDS in the absence of arbitrage. See Duffie and Singleton (2003) for a detailed discussion of this and more complex cases. 
We also regress the premium on each of these regressors separately to get a better idea of the explanatory power of each regressor

$$
\begin{gathered}
S_{i, t}=\alpha_{i}^{l}+\beta_{i}^{l} \operatorname{lev}_{i, t}+\varepsilon_{i, t} . \\
S_{i, t}=\alpha_{i}^{l}+\beta_{i}^{v} \operatorname{vol}_{i, t}+\varepsilon_{i, t} . \\
S_{i, t}=\alpha_{i}^{l}+\beta_{i}^{r} r_{t}^{10}+\varepsilon_{i, t} .
\end{gathered}
$$

CT and CDMW use similar regressions to investigate the importance of these theoretical variables for the determination of credit spreads on corporate bonds. CGM focus on changes in credit spreads, perhaps because differences are harder to explain than levels and a regression in differences therefore should provide a more stringent test of the theory. We therefore also estimate regressions (1)-(4) in differences.

$$
\begin{gathered}
\Delta S_{i, t}=\alpha_{i}^{d}+\beta_{i}^{l} \Delta l e v_{i, t}+\beta_{i}^{v} \Delta \operatorname{vol}_{i, t}+\beta_{i}^{r} \Delta r_{t}^{10}+\varepsilon_{i, t} . \\
\Delta S_{i, t}=\alpha_{i}^{d}+\beta_{i}^{l} \Delta l e v_{i, t}+\varepsilon_{i, t} . \\
\Delta S_{i, t}=\alpha_{i}^{d}+\beta_{i}^{v} \Delta v o l_{i, t}+\varepsilon_{i, t} \\
\Delta S_{i, t}=\alpha_{i}^{d}+\beta_{i}^{r} \Delta r_{t}^{10}+\varepsilon_{i, t} .
\end{gathered}
$$

\section{Empirical Analysis}

\subsection{Data}

To investigate the regressions suggested by theory, we require data on credit default swap premia, firm leverage, volatility and riskless yields. We obtain these data from the following sources: 
Credit Default Swap premia: We use quotes from the CreditTrade Market Prices database for 1999-2002 corresponding to credit default swaps on senior debt. The CDS market has experienced considerable growth over this period. Figure 1 depicts the evolution of the number of daily available quotes.

Only the contracts on companies for which we have data in CRSP and COMPUSTAT are used in our study. The North America Industry Classification System (NAICS) code was obtained for each company from FISD and WRDS. Using the NAICS code, utilities and financial companies were excluded. Since there are very few quotes on junior debt, these quotes are excluded. The amount of quotes satisfying the above criteria is 53,625 . Figure 2 depicts the number of quotes as a function of the tenor. The market is clearly concentrated on maturities around 5 years. We therefore only retain 48,626 quotes that have tenors between 4.5 and 5.5 years. This sample represents $90.7 \%$ of all quotes.

Even though the CDS market is a worldwide market, the majority of the quotes fall within New York trading hours. This finding is to a large extent due to our selection criteria, because CRSP and COMPUSTAT mainly contain data on US companies. From the 48,626 quotes, we selected, for each day and reference entity, the quote closest to 4PM NY time. More precisely, we filter the quotes according to the following criteria:

- Either the time stamp is after $3 \mathrm{PM}$

- or the time stamp is between 12 noon and 3PM and the time stamp on the previous available quote is more than two trading days old

- or the time stamp is between 9AM and 12 noon and the time stamp on the previous available quote is more than three trading days old

- or the time stamp is between 6AM and 9AM and the time stamp on the previous available quote is more than four trading days old

- or the time stamp is between $3 \mathrm{AM}$ and $6 \mathrm{AM}$ and the time stamp on the previous available quote is more than five trading days old.

This rule is motivated by consideration for the difference regressions. To compute the differences in the premia, we ideally want quotes at the exact same time of the day. This is not possible and because of sample size considerations, it is also not possible to limit 
ourselves to time stamps after 3PM. By including quotes with time stamps further removed from $4 \mathrm{PM}$, the potential for biases in the computed premium differences increases. However, by only selecting quotes farther removed from $4 \mathrm{PM}$ if the previous quote is further removed in time, we ensure that the potential bias from time stamps at different parts of the day is reduced.

Bid and offer quotes are treated separately. As a final filter, we only retain firms with at least 25 quotes or changes in quotes, depending on the regression specification. It should be noted that the number of observations in any given regression will depend on whether it is run on levels or differences and on whether bids or offers are used. This leaves us with 4813 bid and 5436 offer quotes over the whole sample period, with slightly fewer observations for regressions in differences. The Appendix lists the companies that are included in the sample for the different regressions.

The data for the theoretical determinants of the CDS premia (the explanatory variables in the regressions) are constructed as follows:

Leverage: The leverage ratio is defined as

$$
\frac{\text { Book Value of Debt }+ \text { Book Value of Preferred Equity }}{\text { Market Value of Equity }+ \text { Book Value of Debt }+ \text { Book Value of Preferred Equity }}
$$

The Market Value of Equity was obtained from CRSP, and the Book Value of Debt and the Book Value of Preferred Equity from COMPUSTAT. Since book values are only available at the quarterly level, we linearly interpolate in order to obtain daily figures.

Volatility: A time series of equity volatility was computed for each company using an exponentially weighted moving average model on daily returns obtained from CRSP. ${ }^{13}$ In the empirical literature on the determinants of corporate bond spreads, our approach is closest to that of CT, who construct historical volatility based on 180 days of returns in their base case regressions. CGM use the VIX data, which represents option-implied volatility based on S\&P 100 index options. CDMW use both volatility implied by individual equity options as well as historical volatility.

Treasury Bond Yields: Daily data on 10-year Treasury bond yields were collected from DataStream. We use the appropriate constant maturity index constructed by the US

\footnotetext{
${ }^{13}$ For each reference entity, volatility $h_{t}$ was generated according to $h_{t}=r_{t}^{2}(1-\lambda)+h_{t-1} \lambda$, with $r_{t}$ denoting daily returns. In order to obtain a more precise estimate of $\lambda$, we constrain this parameter to be the same across firms in the estimation.
} 
Treasury based on the most actively traded issues in that maturity segment.

Table 1 and Figure 3 provide descriptive statistics and visual summaries of the CDS premia and the explanatory variables used in the main regressions. The CDS premium is 180 basis points on average with a large standard deviation. The explanatory variables seem to be less variable than the CDS premium and especially the 10-year yield is tightly centered around the mean. From Figure 3 it would seem that the high variability of the CDS premium is partly due to the fact that the premium has been increasing over time, regardless of the rating of the reference obligation, and that the premium differs considerably across reference obligations with different ratings. Figure 3 also clearly indicates that the number of available datapoints is very different for different reference obligations.

Because the data set has a cross-sectional as well as a time-series dimension, several aspects of the relationship between the theoretical variables and the credit spreads can in principle be investigated. Cross-sectional correlations indicate how credit spreads differ between companies because of differences in leverage and volatility. Time-series correlations indicate how credit spreads change for a given company as the company's leverage ratio and equity volatility change. Table 1 presents some initial insight into these correlations and the differences between the cross-sectional and time-series patterns. Time-series as well as cross-sectional correlations between the CDS premia and the theoretical variables have the expected sign, and interestingly for both volatility and leverage the cross-sectional correlation is not very different from the time-series correlation. Figures 4 through 7 provide additional insight into this issue. Figures 4 and 5 graphically illustrate the time-series relationship with the CDS premia for leverage and volatility respectively by averaging the variables across firms at a point in time. Because our data are unevenly spaced, we use weekly averages. The figures clearly suggest a positive time-series relationship between either theoretical variable and the CDS premium. Figures 6 and 7 graphically illustrate the cross-sectional relationship between the variables and the CDS premia by averaging the data across time for a given firm. While the figures suggest a positive relationship for volatility as well as leverage, they clearly confirm the result in Table 1 that the correlation is higher for volatility. 


\subsection{Regression Results}

Because the regressions (1)-(8) have a cross-sectional as well as a time-series dimension, they can be implemented in different ways. We first follow CGM and present results on average regression coefficients obtained by running a series of time-series regressions for every different company, emphasizing time-series correlations between CDS premia and theoretical variables. From a managerial perspective, these regressions are of most interest because they indicate how credit spreads change for a given company as the company's leverage ratio and equity volatility change. Subsequently, for the levels regressions (1)-(4) we also present results obtained using a number of different panel data techniques. Regarding the implementation of the regressions, note that the constant in the difference regressions is obviously different (at a theoretical level) from the constant in the levels regressions, which is why it is indexed with a superscript $l$ or $d$, respectively. The constant is also indexed by a subscript $i$, because in the implementation using time-series regression it is different for every company. In the panel data implementation, this is the case when estimating fixed-effects but not for the OLS panel data regression which constrains the constant to be the same for all companies.

Table 2 presents the results of the levels regression (1) and the difference regression (5). For both regressions, we report results obtained with bid quotes as well as results obtained with offer quotes. In each case, we report results obtained using data on all companies, and we also report results for a sample of companies with below median rating and another sample of companies with above median rating. The number of companies included in each analysis is listed in the third row from the bottom. The next to last row indicates the average number of observations included in the time-series regressions, and the last row indicates on average how much time elapses between different quotes for the same underlying. For each case, the top four rows list the average regression coefficients obtained from the time-series regressions. Rows 5 through 8 present the t-statistics obtained by computing standard errors on the estimated regression coefficients.

A number of important conclusions obtain. First, the estimated sign for the coefficient on leverage is always positive, as expected a priori. Second, the estimated sign for the coefficient on volatility is also always positive, as expected. Third, the coefficient on the 10-year yield also conforms to theoretical expectations because it is estimated with a negative sign. What is even more encouraging is that the t-statistics almost uniformly indicate statistical 
significance at conventional significance levels. Interestingly, the few exceptions occur for the levels regressions, not for the (more challenging) difference regressions.

The point estimates for the coefficients are remarkably similar across the levels and difference regressions, least so for the coefficients on the 10-year yield. Not surprisingly, there are some differences in the point estimates across ratings. For lower rated firms, the point estimates for leverage and volatility are bigger than for higher rated firms. These effects are perfectly intuitive and consistent with the predictions of any structural credit risk model. We also find that CDS premia for lower rated firms are more sensitive to interest rates. Again, this is consistent with the theory. It is also consistent with the empirical findings of Duffee (1998) on corporate bond yield spreads. ${ }^{14}$

A final statistic of interest is the adjusted $R^{2}$. First and foremost, the explanatory power of the levels regressions is of course much higher than that of the difference regressions. For the levels regressions, the theoretical variables explain approximately $60 \%$ of the variation in the premium. For the difference regressions, the theoretical variables explain approximately $23 \%$. The R-squares for the lower ratings are always a bit higher than those for the higher ratings, as expected. It may also be of interest that in the level regressions the R-squares for the bid quotes are a bit higher than the R-squares for the offer quotes, even though this pattern does not show up in the difference regressions.

While the effects of a change in the yield curve somewhat depend on whether one estimates in levels or differences, the results for volatility and leverage are robust across specifications. This renders the economic interpretation of the point estimates of significant interest. Using the estimation results for all companies, an 1\% increase in (annualized) equity volatility raises the CDS premium on average by approximately $0.8-1.5$ basis point. For companies with lower ratings, the effect is estimated to be between 1.1 and 2.3 basis points. The leverage effect is also stronger for lowly rated companies: a $1 \%$ change in the leverage ratio increases their CDS premium by approximately 6-10 basis points, whereas this effect is between 4.8 and 7.3 basis points when considering all companies.

Tables 3, 4 and 5 further explore these results. Table 3 presents results for regressions (2) and (6), Table 4 for regressions (3) and (7), and Table 5 for regressions (4) and (8). The

\footnotetext{
${ }^{14}$ In a structural model, the risk adjusted probability of default is decreasing in the risk free interest rate. Intuitively, a higher risk free rate entails a higher drift rate for the firm's asset value and allows it to grow its way away from financial distress. See also Longstaff and Schwartz (1995).
} 
tables are structured in the same way as Table 2. It must be noted that, in a sense, the point estimates in these tables are of somewhat less interest than those in Table 2, because the regression in Table 2 is the one suggested by the theory. It is therefore entirely possible that in the univariate regressions in Tables 3 through 5 , coefficients are biased because of an omitted variable argument.

Interestingly however, the signs of the point estimates are the same as in Table 2 and the t-statistics for the time-varying regressors are significant at conventional significance levels. Table 3 indicates that when leverage is the only explanatory variable, its economic effect is always estimated to be larger than in Table 2, and the same is true for volatility in Table 4, but the effects are roughly of the same order of magnitude. A comparison of the R-squares in Tables 3-5 with those in Table 2 indicates to what extent each of the theoretical variables contributes to the explanatory power of the regression. It can be seen that each of the three variables has some explanatory power, even though the leverage variable clearly dominates the other two regressors. The leverage variable alone explains between $37.1 \%$ and $45.7 \%$ of the variation in CDS premia in the levels regressions, but only about $13 \%$ on average in the difference regressions. Volatility explains between $23.9 \%$ and $29.7 \%$ in the levels regressions, but only between $6.9 \%$ and $14.4 \%$ in the difference regressions. Interestingly, the 10-year yield variable has a higher R-square than the volatility variable in the levels regression, but its explanatory power in the difference regressions is decidedly modest.

Note that the negative correlation between CDS premia and the risk free rate discussed above has also been documented for bond yield spreads by Longstaff and Schwartz (1995) and Duffee (1998). Presently, no consensus prevails as to the economic reasoning behind this stylized fact. Duffie and Singleton (2003) state that one possible explanation for the negative correlation is the existence of stale corporate bond prices. The spreads are measured by taking the difference between the corporate and the Treasury yield curves; therefore, an increase in Treasury yields might be associated with a decrease in spreads until the recorded corporate bond price accounts for the change. Our results rule out the latter explanation because default swap premia are not given by the difference of two yields as bond spreads are. However, our results are consistent with the implication of structural models that an increase in the risk free rate will decrease risk-adjusted default probabilities. ${ }^{15}$

In summary, we conclude that there are some interesting differences between the levels

\footnotetext{
${ }^{15}$ See Longstaff and Schwartz (1995) for a discussion.
} 
and difference regressions in Tables 3-5.

\subsection{Robustness Analysis}

This Section further investigates the robustness of the regression results presented in Section 3.2. In a first step, we estimate the regression proposed by CGM. Their base case regression includes the explanatory variables $l e v_{i, t}, v l_{i, t}$ and $r_{t}^{10}$ included in (1) but adds a number of other explanatory variables including

Treasury Bond Yields: We collected daily series of 2-year and 10-year bond yields from DataStream.

The Slope of the Yield Curve: Defined as the difference between the 10-year Treasury bond yield used in regression (2) and 2-year Treasury bond yields also obtained from DataStream. We use the 2-year Treasury bond yield as the level of the yield curve in order to make the interpretation of the slope more straightforward.

The square of the 2-year yield.

The return on the S\&P 500: Daily data on the return on the S\&P 500 was obtained from DataStream.

The slope of the smirk: We estimate the slope of the smirk on equity options using out-of-the-money S\&P 500 American futures put options from the CME Futures and Options Database. A number of choices have to be made as regards these calculations. First, implied volatilities are computed using the American options analytical approximation technique proposed by Whaley (1986). Second, we cannot simply compute the smirk using one particular maturity because the same maturity is not available on every trading day. To take into account the dependence of the smirk on maturity, we define moneyness as $\ln (K / F) / \operatorname{sqrt}(T)$, were $K$ is the strike price, $F$ is the futures price, and $T$ is the time to expiration. Standardizing moneyness by $\operatorname{sqrt}(T)$ makes the slope of the smirk (on a given trading day) remarkably similar across expirations. Third, we estimate a linear relation between moneyness and implied volatility. ${ }^{16}$ Robustness tests demonstrate that adding a quadratic term does not change the results. Fourth, we arbitrarily choose 45 days as a benchmark maturity. The slope of the 45-day smirk is then obtained from linearly interpolating the coefficients

\footnotetext{
${ }^{16}$ To circumvent the noise in very deep out-of-the-money options, we ignore options whose moneyness was lower than the median across time of the lowest moneyness of each trading day.
} 
corresponding to the nearest available expirations.

The motivation for including these variables is as follows. The interest rate variable directly modeled by most of the theory is the instantaneous spot rate. It has been shown empirically that the instantaneous rate can be explained by a number of term structure variables. The yield on long maturities used in regression (1) is one of these variables. Alternatively, one can use the yield on short maturity bonds or the difference in yield between short and long maturities, which is what is proposed here. The square of the 2-year yield is a convenient attempt to exploit nonlinearities in the relationship between term structure variables and credit default swap premia. CGM (2001) use the return on the S\&P 500 to proxy for the overall state of the economy and the slope of the smirk to proxy for jumps in firm value. It is clear that some of these variables are more loosely related to theory compared to the regressors in (1). For additional motivation see CGM. Including these explanatory variables leads to the levels regression

$$
S_{i, t}=\alpha_{i}^{l}+\beta_{i}^{l} \operatorname{lev}_{i, t}+\beta_{i}^{v} \operatorname{vol}_{i, t}+\beta_{i}^{r} r_{t}^{2}+\beta_{i}^{r 2}\left(r_{t}^{2}\right)^{2}+\beta_{i}^{r 3} \text { tsslop }_{t}+\beta_{i}^{s p} S \& P_{t}+\beta_{i}^{s m} \text { smslop }_{t}+\varepsilon_{i, t} .
$$

and the difference regression

$\Delta S_{i, t}=\alpha_{i}^{d}+\beta_{i}^{l} \Delta l e v_{i, t}+\beta_{i}^{v} \Delta v o l_{i, t}+\beta_{i}^{r} \Delta r_{t}^{2}+\beta_{i}^{r 2}\left(\Delta r_{t}^{2}\right)^{2}+\beta_{i}^{r 3} \Delta t s s l o p_{t}+\beta_{i}^{s p} \Delta S \& P_{t}+\beta_{i}^{s m} \Delta$ smslop $_{t}+\varepsilon_{i, t}$

Table 6, which presents the results of these regressions, has the same format as Table 2 . The t-statistics were computed in the same fashion. One objective of this table is to verify by means of the R-squares if the addition of these variables increases the explanatory power of the theory. For the difference regressions, the extra variables increase the R-square by roughly $7.5 \%$, whereas for the levels regressions the increase in the R-square is approximately $14 \%$. Interestingly, the increase in R-square is larger for the regressions that use offer quotes. The term structure variables are often insignificantly estimated, perhaps suggesting some multicollinearity between them, or high correlation with another explanatory variable. The return on the S\&P 500 has a significantly estimated negative impact on the CDS premium, indicating that in times with high returns (good times), the premium narrows. This finding is consistent with the findings in CGM for spreads on corporate bonds. The slope of the smirk seems to have a minor impact on the CDS premium. Finally and perhaps most 
importantly, the point estimates for leverage and volatility are very similar to the ones in Table 2. We therefore conclude that the magnitude of the effects discussed before is robust to the inclusion of a number of other variables. This is remarkable if one considers that the R-square increases considerably, and that in the levels regression we have a specification in Table 6 that explains a large part of the variation in CDS premia. These results therefore inspire confidence in our estimates.

It could be argued that the t-statistics in Tables 2 through 6 are hard to interpret because they are computed based on the variation in regression coefficients for time-series regressions. An alternative approach is to treat the empirical problem as a full-fledged panel data problem. Tables 7 and 8 present the results of this procedure for the levels regressions. We do not report panel estimation for the difference regressions because we need a number of additional assumptions regarding cross-sectional correlation patterns and autocorrelations to compute standard errors, and the levels regressions are sufficient to make the point.

For all three panels in Tables 7 and 8, columns 1-4 report results for estimation of regressions (1), (2), (3) and (4). Table 7 reports results for offer quotes and Table 8 for bid quotes. Panel A reports results for the basic OLS panel regression, Panel B allows for reference entity fixed effects and Panel $\mathrm{C}$ includes quarter dummies. In Panel A, each observation is treated independently and the regression constant is assumed to be the same across companies.

The point estimates in Panel A again have the signs predicted by theory, although their magnitudes differ from the firm by firm time-series regressions in Tables 2-6. The coefficient for leverage tends to be smaller while equity volatility enters with a larger coefficient. When, as in Panel B, fixed effects for the reference entities are included, the parameter estimates fall back in line with what was found in Tables 2-6, while the R-squares increase substantially. This clearly indicates that there is a large amount of cross-sectional variation that cannot be captured by the theoretical variables. The main effect of including quarter dummies (Panel C) is a slight increase in the R-square of the regression relative to the base case in Panel A. This can be interpreted as suggesting that the theoretical variables explain most of the time-series variation in the data, but the results of this regression may be hard to interpret. The results will be affected by inserting more time dummies into the equation, and the choice of quarterly dummies is ad hoc. Note however that because we have daily data and an unbalanced panel, there is no natural choice for the frequency of the time dummies: 
quarterly dummies are as good a choice as any. The t-statistics are much higher in Tables 7 and 8, which is not necessarily surprising because the t-statistics in Tables 2-6 are essentially computed on the variation in the regression coefficients and therefore hard to relate to the more conventional t-statistics in Tables 7 and 8 .

Despite some of the problems with the interpretation of the time dummies, the relative increases in explanatory power resulting from including fixed effects and time dummies respectively suggests that the variables determined by theory may have more explanatory power in a time series than a cross-sectional sense. In this respect, it is interesting to note that the ranking of the R-squares for the univariate regressions on leverage and volatility (in Tables 3, 4, 7 and 8) differs depending on whether the data is treated as a collection of time series or as a panel. In the time series case, the R-squares are higher when leverage is used as regressor compared to equity volatility. In Panels A of Tables 7 and 8, the equity volatilities appear to be more successful in explaining the variation in CDS premia. This is consistent with leverage having more explanatory power in the time series, whereas volatility is relatively speaking better at explaining the cross section. Returning to Table 1, we can see that the reported cross-sectional and time series correlations are consistent with this observation. For leverage, the cross-sectional correlation is lower than the time-series correlation, while it is the opposite for volatility. One possible explanation is that theoretically, leverage does not provide sufficient information about the likelihood of financial distress since it does not convey information about business risk. Equity volatility, on the other hand, provides information about both asset risk and leverage, and can thus be better used to discriminate between the credit risk of different firms.

Finally, note that the cross-sectional and time-series correlations in Table 1 also help to explain the differences in the point estimates between Panel A of Tables 7 and 8 on the one hand and Panel B (as well as Tables 2-4) on the other hand. The fixed effects regressions in Panel B capture the time-series correlation. Because the results in Panel A capture a mixture of time-series and cross-sectional correlation, the point estimate for leverage goes down and that for volatility goes up, consistent with the relative strength of the effects documented in Table 1. It is interesting to note that the small differences between the time-series and cross-sectional correlations documented in Table 1 leads to relatively large changes in point estimates. 


\subsection{Discussion}

It is interesting to compare these results with the results obtained for spreads on corporate bonds by CT, CGM and CDMW. The most important observation is that our results confirm the results in these papers that the theoretical determinants of credit risk are empirically relevant and estimated with the sign predicted by theory. With respect to the explanatory power of these theoretical variables, a comparison is unfortunately less straightforward. CGM use a market-wide measure of volatility. They estimate difference regressions and their basecase regressions are the ones in Table 6. The R-squares in CGM are considerably lower. They also obtain much lower R-squares than we do when studying the effects of leverage in isolation. Our point estimates for the effects of leverage and volatility are larger than theirs, but it must of course be noted that our measure of volatility is very different. CT investigate level regressions and focus mainly on the effect of volatility. They also use a historical measure of volatility and because they use panel regressions their results are most closely related to those of Tables 7 and 8. In general they obtain higher R-squares than we do, but this finding must be interpreted with caution because they include a number of control variables which explain approximately $25 \%$ of all variation. The estimate of a $1 \%$ change in annualized volatility in $\mathrm{CT}$ is 14 basis points, considerably higher than our estimate.

Some of the empirical results in CDMW are closely related to the ones in this paper because they investigate the explanatory power of volatility in the absence of other explanatory variables. However, they do not consider the impact of leverage. CDMW use panel regressions and the R-squares and point estimates in their base-case regressions ought to be compared to the ones in Tables 7 and 8 . It is noteworthy that their point estimates for the firm implied volatility are very similar to the ones we obtain using historical volatility. This is likely due to the fact that we compute volatility as an exponentially weighted moving average, which like implied volatility is more variable than a 180 day historical average.

In summary, the explanatory power of the theoretical variables in our analysis differs from the results in the literature on corporate bond spreads, which itself contains some divergent results. It must be noted that it may be problematic to try to relate the explanatory power of regressions for corporate bond spreads to those for CDS premia. The reason is that the explanatory power of the regressions depends on maturity (see CT, CGM and CDMW). 
Because the maturity of the Credit Default Swaps in our sample (roughly five years) may be very different from the average maturity for corporate bonds, this may compromise a comparison of R-squares between the two markets.

\subsection{Analyzing the Regression Residuals}

One robust conclusion from Tables 2-8 is that the theoretical determinants of CDS premia are estimated statistically significantly with signs that confirm our intuition and that the magnitude of these effects is also intuitively plausible. However, it is difficult to determine how successful theory is in explaining the variation in CDS premia. The R-squares of the explanatory regressions vary considerably dependent on whether one analyzes levels or differences, and on whether one uses panel data or time series techniques. Moreover, we do not necessarily have good benchmarks for the R-squares, because comparisons with empirical results for the corporate bond market are subject to problems.

We therefore attempt to provide more intuition for the explanatory power of the theoretical determinants of CDS premia. To understand the structure of the remaining variation in the data after controlling for the theoretical determinants of CDS premia, we analyze the regression residuals from the levels regression (1) and the difference regression (5) using principal components analysis (PCA). By analyzing the correlation matrix of the errors of the time-series regressions, we investigate if there exists an unidentified common factor that explains a significant portion of the variation of the errors. The structure of the data somewhat complicates the analysis, and we performed a number of different analyses in order to investigate the robustness of our conclusions. There are two types of complications in the data. First, the data are non-synchronous. Second, the number of observations differs considerably by company. The first complication causes some difficulties at a technical level. The second complication forces us to make some choices regarding the use of the data.

We first report on an analysis of the levels regression (1), using the correlation matrix of the regression errors for the 15 companies with the highest number of observations. We limit ourselves to a small number of companies to obtain results that are based on as much timeseries information as possible. We also analyze the correlation matrix of the CDS premia $S_{i, t}$. For premia and errors from the levels regressions, a simple approach to the non-synchronicity problem is available. We artificially construct observations every 7 calendar days, by linearly 
interpolating from the closest (in time) two observations. This results in a balanced panel of errors. Panel A of Table 9 shows that for the bid quote levels, the first principal component is fairly important, explaining $58.7 \%$ of the variation. The first eigenvector has mostly positive elements of similar magnitude, with a few exceptions. The first principal component of the errors has more diverse weights, and it explains only $32.5 \%$ of the variation of the errors. The results for offer quotes in Panel B support those from Panel A. The first principal component for the errors explains only $31.0 \%$ or the error variation. The difference between the explanatory power of the first principal component of the premium difference and that of the errors is approximately 25\%, similar to the difference in Panel A. A comparison between these R-squares suggests that a substantial part of the common variation of the premia is explained by the regressors.

Table 10 repeats the analysis of Table 9, using the 15 companies with the highest number of observations, but uses the errors of the time-series regressions in differences (5). For differences, a simple interpolation does not work because there is more than one time index. Instead, each element of the correlation matrix has to be estimated individually. We do so by using the procedure of de Jong and Nijman (1997). ${ }^{17}$ Because the estimated correlation matrix is not generally positive semidefinite, we compute the positive semidefinite matrix closest to the estimated correlation matrix according to the Frobenius-norm using a numerical algorithm due to Sharapov (1997) and also used by Ledoit, Santa-Clara, and Wolf (2003).

Panel A of Table 10 shows that for the differences in bid quotes the first principal component is fairly important, explaining $50.2 \%$ of the variation, with a first eigenvector that has only positive elements. In contrast, the first principal component of the errors has positive and negative elements, and it explains only $24.5 \%$ of the variation of the errors. The results for offer quotes in Panel B are a bit weaker but support those from Panel A. In this case the first principal component of the errors contains only one negative element, but the weights of the first principal component of the differences in offer quotes are remarkably more homogeneous. Most importantly, the first principal component for the errors explains only $30.8 \%$ or the error variation.

Our third PCA is closer in spirit to the one in CGM, although it is slightly different

\footnotetext{
${ }^{17}$ Martens (2003) reviews and compares different methods for computing covariance matrices for nonsynchronous data. His simulations show that the de Jong and Nijman (1997) method is the most reliable in the absence of a bid-offer spread. Given that we work with either bids or offers, we choose this method.
} 
because of data constraints. CGM perform a PCA by distributing the errors of all the companies in the sample in bins according to the maturity of the bonds and the leverage of the issuing companies. With a balanced panel, it is straightforward to do this analysis for differences. In our case, we do not observe the premia at fixed intervals. As a result, changes in premia and the corresponding errors carry a double time index, and it is not feasible to assign them to bins. We therefore limit ourselves to a PCA using bins for the levels regressions (1).

CGM construct fifteen bins by classifying the companies in 5 leverage groups and the bonds in three maturity ranges. However, because all CDSs in our sample have (roughly) a 5 -year maturity, it is not feasible to use maturity as a classification variable. Also, we have only one kind of CDS per company, and not a collection of bonds. Therefore we construct our bins using only the leverage dimension, so that we have 5 bins delimited by the quintiles of the distribution of leverage of the different companies. The time interval defining the bins is 15 days. Table 11 reports on this analysis. The first principal component for the bid (offer) errors explains only $35.6 \%(36.4 \%)$ of the variation of the bins, compared to $68.6 \%$ (66.1\%) for the bid (offer) quotes.

Overall, the three tables allow for a remarkably robust conclusion. The PCAs for the levels and differences suggest that the theoretical determinants of default swap premia do explain a significant part of the common variation. Regarding the percentage of the variance explained by the first principal component in the error analysis, it varies dependent on whether one uses bins and whether one uses differences or levels, but it varies between $20 \%$ and $36 \%$. A high percentage in this case would indicate that there is a lot of common variation left which cannot be explained by on of the theoretical variables. However, we find it difficult to draw strong conclusions from this range of numbers as to the validity of the theoretical variables, because it is not clear what the benchmark is. Compared with the findings in CGM, the percentage variation explained by the first principal component in the errors is certainly low. It must also be taken into account that the largest eigenvalues are in general severely biased upward, as observed by Ledoit and Wolf (2004).

To further understand the nature of the residuals, we also ran regressions (1) and (5) with a CDS market index included. One would expect such an index to have substantial explanatory power for residual CDS premia if the variables suggested by theory are inadequate. Unfortunately no index is available for the CDS market over our entire sample. We 
use the TRACERS index, which is available from September 2001 to the end of our sample and we repeat our estimation exercise with the CDS data available for this period (not reported). ${ }^{18}$ It must be noted that although this covers less than half of the time period of our CDS sample, it covers the majority of the datapoints because the number of quotes increases through time. Interestingly, we find that including the market index does not noticeably affect the explanatory power of the regression. We therefore conclude that these results confirm those from Tables 9-11: the theoretical variables perform adequately in explaining CDS spreads.

\section{Conclusion}

Using a new dataset of bid and offer quotes for credit default swaps, we investigate the relationship between theoretical determinants of default risk and actual market premia. These determinants are firm leverage, volatility and the riskless interest rate. We find that these variables are statistically significantly estimated and that their effect is economically important as well as intuitively plausible. Moreover, the estimates of the economic effects of leverage and volatility are very similar regardless of whether one estimates on levels or differences and regardless of the econometric methodology. A 1\% increase in annualized equity volatility raises the CDS premium by 1 to 2 basis points. A $1 \%$ change in the leverage ratio raises the CDS premium by approximately 5 to 10 basis points. These effects are not out of line with some of the estimates available in the literature on corporate bond spreads, even though Campbell and Taksler (2003) estimate a stronger effect of a change in volatility.

While these estimated effects are very robust and intuitively plausible, it is difficult to determine how successful the theory is in explaining the variation in the sample of CDS premia. The explanatory power of the theoretical variables depends on the econometric method and on whether one uses levels of differences. Using time series regressions the R-square for changes in default swap premia is approximately $23 \%$, and the explanatory power for the levels of the premia is approximately $60 \%$. The R-square for levels regressions goes up to more than $70 \%$ if we add in other explanatory variables as in Collin-Dufresne and Goldstein (2001). For a number of reasons it is difficult to relate these numbers to the

\footnotetext{
${ }^{18}$ Morgan Stanley's TRACERS index is a synthetic index of US investment grade credit based on a selection of the most liquid reference entities.
} 
available literature on other securities such as corporate bonds. However, our analysis of the residuals, coupled with the high R-squares for most of the levels regressions, leads us to cautiously conclude that the theory is successful in explaining the variation in CDS premia.

These results suggest a number of interesting questions. First, given that the variables critical for structural models of credit risk seem to be important for explaining CDS premia, how successful are structural models in explaining the data? One can think of the linear regressions in this paper as a first-order approximation to any structural model, suggesting that structural models may work well, but CT find that this logic does not extend to the Merton model when explaining corporate bond spreads. Second, an analysis of the effects of volatility based on individual equity options as in CDMW may prove worthwhile. Third, given that some of the estimated effects are very similar to those estimated in the corporate bond market, a further exploration of the interactions between the corporate bond market and the CDS market may prove worthwhile. Houweling and Vorst (2001) and Longstaff, Mithal, and Neis (2004) document some of these interactions using a reduced-form approach. It may prove worthwhile to explore the interactions between these markets by focusing on structural variables. 


\section{References}

Anderson, R., and S. Sundaresan, 1996, "Design and Valuation of Debt Contracts," Review of Financial Studies, 9, 37-68.

Bakshi, G., D. Madan, and F. Zhang, 2001, "Investigating the Sources of Default Risk: Lessons from Empirically Implementing Credit Risk Models," Working paper, University of Maryland.

BBA, 2003, Credit Derivatives Report 2002/2003, British Bankers' Association.

Black, F., and J. C. Cox, 1976, "Valuing Corporate Securities: Some Effects of Bond Indenture Provisions," Journal of Finance, 31, 351-67.

Black, F., and M. S. Scholes, 1973, "The Pricing of options and corporate liabilities," Journal of Political Economy, 7, 637-54.

Blanco, R., S. Brennan, and I. W. Marsh, 2003, "An Empirical Analysis of the Dynamic Relationship Between Investment-Grade Bonds and Credit Default Swaps," Bank of England working paper no. 211.

Campbell, J. T., and G. B. Taksler, 2003, "Equity Volatility and Corporate Bond Yields," Journal of Finance, 58, 2321-2349.

Collin-Dufresne, P., and R. Goldstein, 2001, "Do Credit Spreads Reflect Stationary Leverage Ratios?," Journal of Finance, 56, 1929-1957.

Collin-Dufresne, P., R. Goldstein, and S. Martin, 2001, "The Determinants of Credit Spread Changes," Journal of Finance, 56, 2177-2207.

Cremers, M., J. Driessen, P. J. Maenhout, and D. Weinbaum, 2004, "Individual Stock-Option Prices and Credit Spreads," Yale ICF Working Paper No. 04-14.

Das, S., and R. Sundaram, 1998, "A Direct Approach to Arbitrage-Free Pricing of Credit Derivatives," NBER working paper no. 6635.

Das, S. R., 1995, "Credit Risk Derivatives," The Journal of Derivatives, 2, 7-23. 
de Jong, F., and T. Nijman, 1997, "High Frequency Analysis of Lead-Lag Relationships Between Financial Markets," Journal of Empirical Finance, 4, 259-277.

Driessen, J., 2004, "Is Default Event Risk Priced in Corporate Bonds?," forthcoming Review of Financial Studies.

Duffee, G., 1999, "Estimating the Price of Default Risk," Review of Financial Studies, 12, $197-226$.

Duffee, G. R., 1998, "The Relation Between Treasury Yields and Corporate Bond Yield Spreads," Journal of Finance, 53, 2225-2241.

Duffie, D., and D. Lando, 2000, "Term Structures of Credit Spreads with Incomplete Accounting Information," Econometrica, 69, 633-664.

Duffie, D., L. H. Pedersen, and K. J. Singleton, 2003, "Modeling Sovereign Yield Spreads: A Case Study of Russian Debt," Journal of Finance, 58, 119-160.

Duffie, D., and K. Singleton, 1999, "Modeling Term Structures of Defaultable Bonds," Review of Financial Studies, 12, 687-720.

Duffie, D., and K. Singleton, 2003, Credit Risk, Princeton University Press.

Elton, E. J., M. J. Gruber, D. Agrawal, and C. Mann, 2001, "Explaining the Rate Spread on Corporate Bonds," Journal of Finance, 56, 247-277.

Eom, Y. H., J. Helwege, and J.-Z. Huang, 2004, "Structural Models of Corporate Bond Pricing: An Empirical Analysis," Review of Financial Studies, 17, 499-544.

Fischer, E. O., R. Heinkel, and J. Zechner, 1989, "Dynamic Capital Structure Choice: Theory and Tests," Journal of Finance, 44, 19-40.

Fisher, L., 1959, "Determinants of the Risk Premiums on Corporate Bonds," Journal of Political Economy, 67, 217-37.

François, P., and E. Morellec, 2004, "Capital Structure and Asset Prices: Some Effects of Bankruptcy Procedures," Journal of Business, 77, 387-412. 
Geske, R., 1977, "The Valuation of Corporate Securities as Compound Options," Journal of Financial and Quantitative Analysis, pp. 541-552.

Houweling, P., A. Mentink, and T. Vorst, 2004, "Comparing Possible Proxies of Corporate Bond Liquidity," forthcoming Journal of Banking and Finance.

Houweling, P., and T. Vorst, 2005, "Pricing Default Swaps: Empirical Evidence," Forthcoming Journal of International Money and Finance.

Hull, J., M. Predescu, and A. White, 2004, "The Relationship Between Credit Default Swap Spreads, Bond Yields, and Credit Rating Announcements," Working paper, University of Toronto.

Hull, J., and A. White, 2000, "Valuing Credit Default Swaps I: No Counterparty Default Risk," Journal of Derivatives, 8, 29-40.

Jarrow, R. A., and S. M. Turnbull, 1995, "Pricing Derivatives on Financial Securities Subject to Credit Risk," Journal of Finance, 50, 53-85.

Jones, E., S. Mason, and E. Rosenfeld, 1984, "Contingent Claims Analysis of Corporate Capital Structures: An Empirical Investigation," Journal of Finance, 39, 611-627.

Jones, E., S. Mason, and E. Rosenfeld, 1985, Contingent Claims Valuation of Corporate Liabilities: Theory and Empirical Tests, University of Chicago Press.

Kim, I., K. Ramaswamy, and S. Sundaresan, 1993, "Does Default Risk in Coupons Affect the Valuation of Corporate Bonds?: A Contingent Claims Model," Financial Management, Special Issue on Financial Distress, Autumn, 117-131.

Lando, D., 1997, Modeling Bonds and Derivatives with Default Risk . pp. 369-393, Cambridge University Press.

Ledoit, O., P. Santa-Clara, and M. Wolf, 2003, "Flexible Multivariate GARCH Modeling with an Application to International Stock Markets," Review of Economics and Statistics, 85, 735-747. 
Ledoit, O., and M. Wolf, 2004, "A Well-Conditioned Estimator for Large-Dimensional Covariance Matrices," Journal of Multivariate Analysis, 88, 365-411.

Leland, H., 1994, "Risky Debt, Bond Covenants and Optimal Capital Structure," Journal of Finance, 49, 1213-1252.

Leland, H., and K. B. Toft, 1996, "Optimal Capital Structure, Endogenous Bankruptcy and the Term Structure of Credit Spreads," Journal of Finance, 51, 987-1019.

Leland, H. E., 1998, "Agency Costs, Risk Management, and Capital Structure," Journal of Finance, 53, 1213-1243.

Longstaff, F. A., S. Mithal, and E. Neis, 2004, "Corporate Yield Spreads: Default Risk or Liquidity? New Evidence from the Credit-Default Swap Market," forthcoming Journal of Finance.

Longstaff, F. A., and E. S. Schwartz, 1995, "A Simple Approach to Valuing Risky Fixed and Floating Rate Debt," Journal of Finance, 50, 789-819.

Lyden, S., and J. Saranati, 2000, "An Empirical Examination of the Classical Theory of Corporate Security Valuation," Barclays Global Investors.

Martens, M., 2003, "Estimating Unbiased and Precise Realized Covariances," Working Paper, Econometric Institute, Erasmus University Rotterdam.

Mella-Barral, P., 1999, "The Dynamics of Default and Debt Reorganization," Review of Financial Studies, 12, 535-578.

Mella-Barral, P., and W. Perraudin, 1997, "Strategic Debt Service," Journal of Finance, 52, $531-556$.

Merton, R. C., 1974, "On the Pricing of Corporate Debt: The Risk Structure of Interest Rates," Journal of Finance, 29, 449-470.

Nielsen, L. T., J. Saa-Requejo, and P. Santa-Clara, 1993, "Default Risk and Interest Rate Risk: The Term Structure of Default Spreads," Working paper, INSEAD. 
Ogden, J. P., 1987, "Determinants of The Ratings and Yields on Corporate Bonds: Tests of Contingent Claims Model," Journal of Financial Research, 10, 329-339.

Perraudin, W., and A. Taylor, 2002, "Liquidity and the Determinants of Bond Market Spreads," Working paper, Birkbeck College.

Sharapov, I., 1997, "Advances in Multigrid Optimization Methods with Applications," Ph.D. thesis, UCLA.

Whaley, R., 1986, "Valuation of American Futures Options: Theory and Empirical Tests," Journal of Finance, 41, 127-150.

Zhou, C., 1997, "A Jump-Diffusion Approach to Modeling Credit Risk and Valuing Defaultable Securities," Working paper, Federal Reserve Board. 


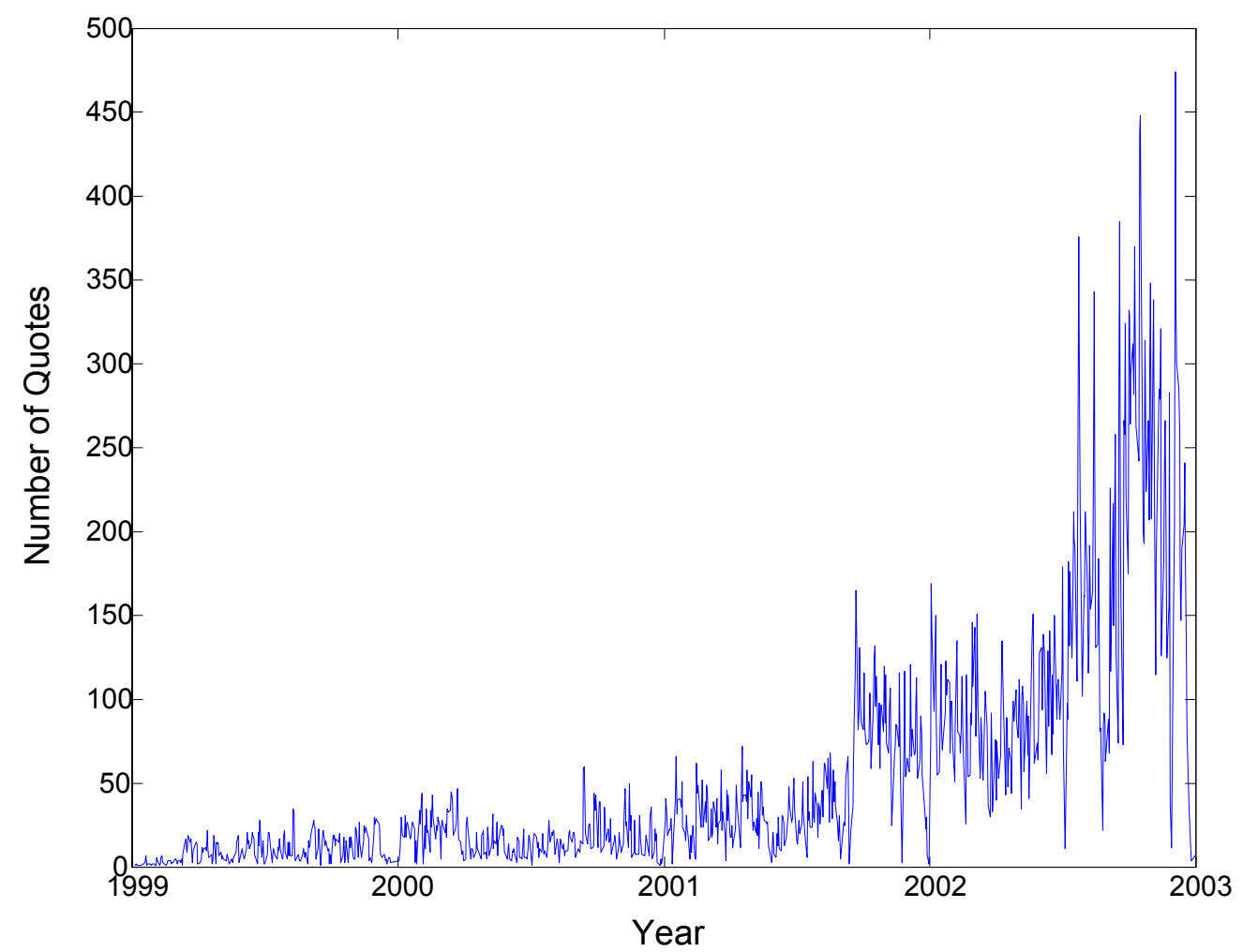

Figure 1: This figure depicts the daily frequency of bid and offer quotes for the CDS premium data during the period January 1999 to December 2002. 


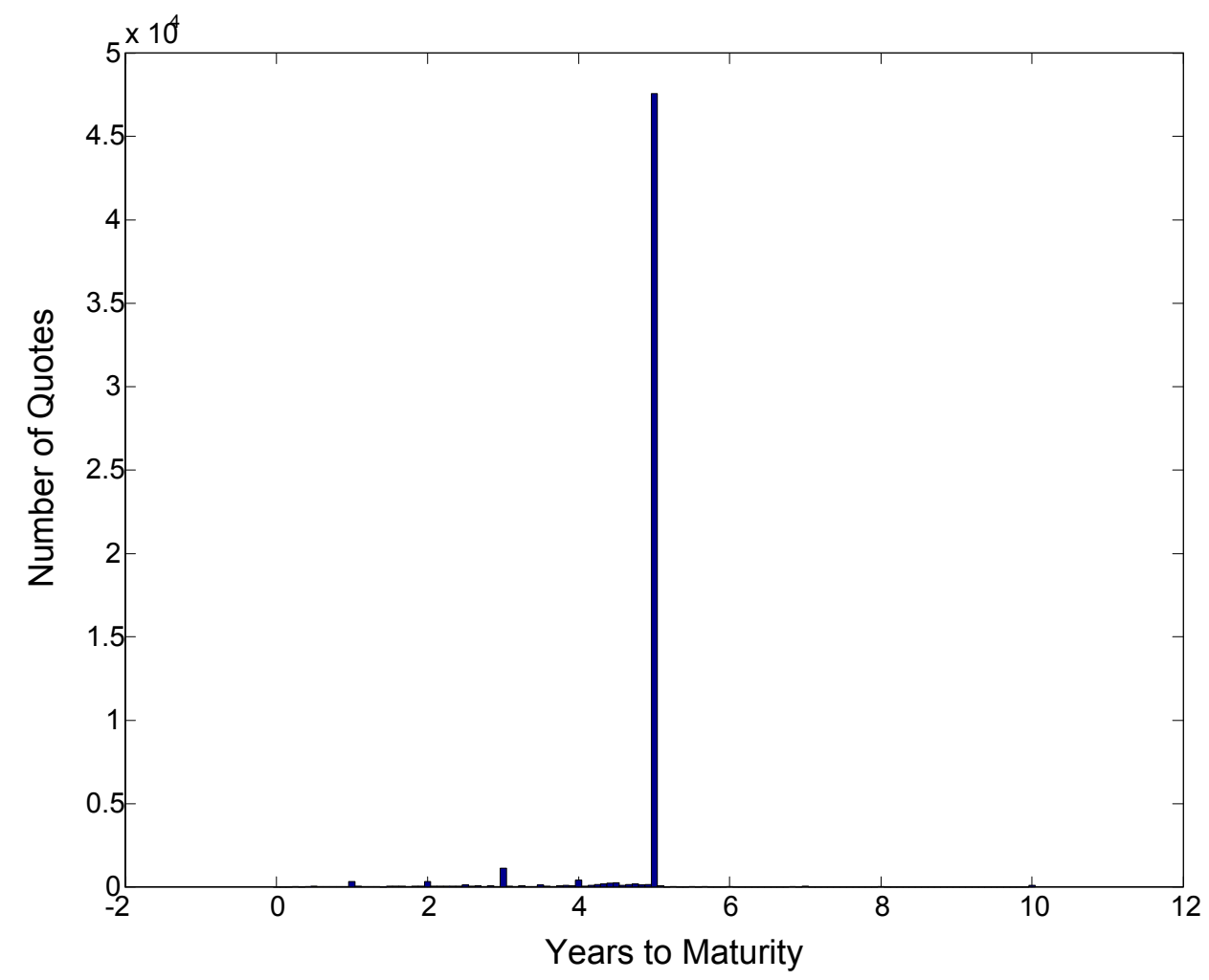

Figure 2: This figure reports a histogram of the maturities of the credit default swaps in our dataset. The figure indicates that the 5 year maturity segment represents the bulk of the market. 

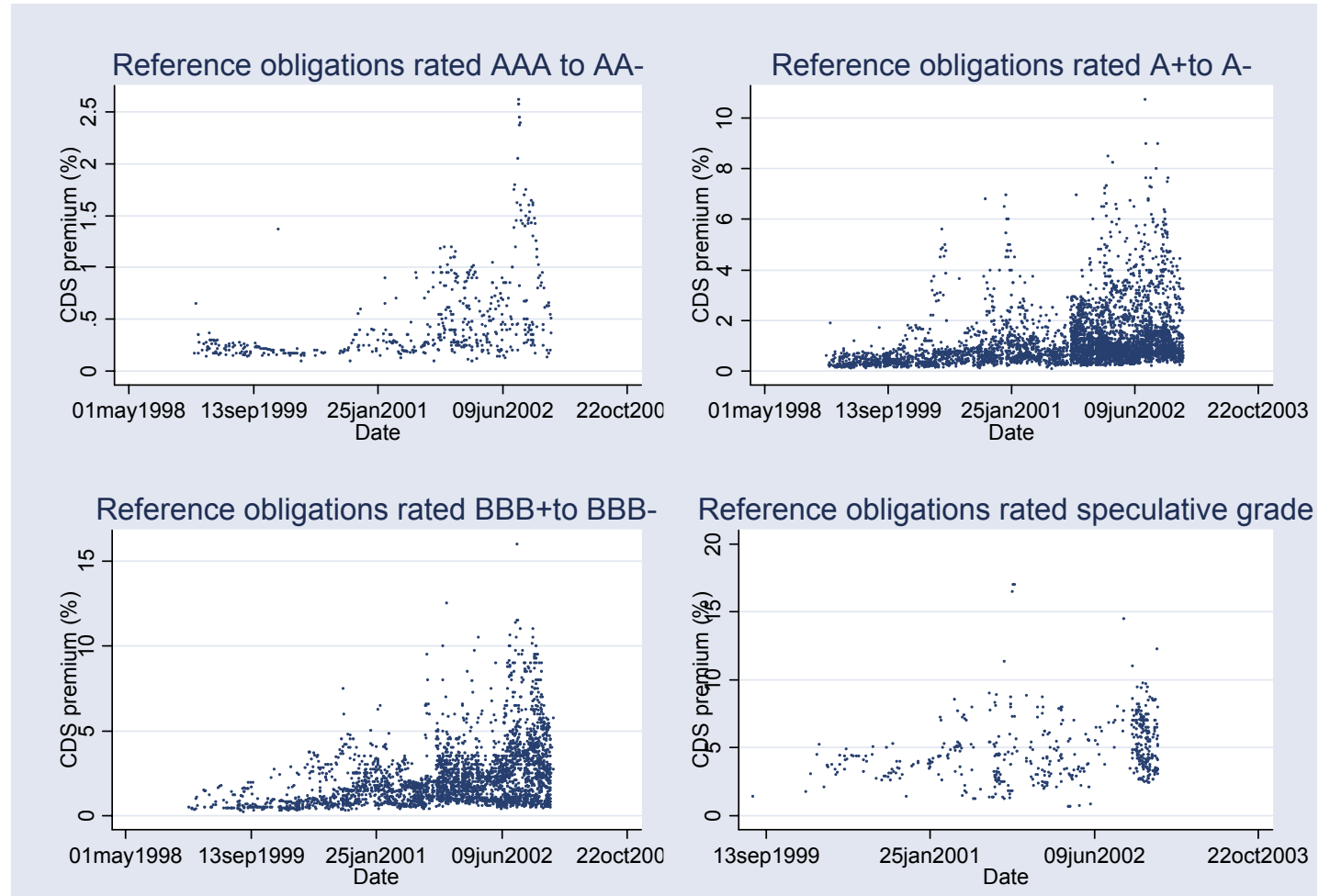

Figure 3: This figure depicts the levels of CDS premia over time and according to rating categories. Data includes bid and offer quotes for all maturities. 


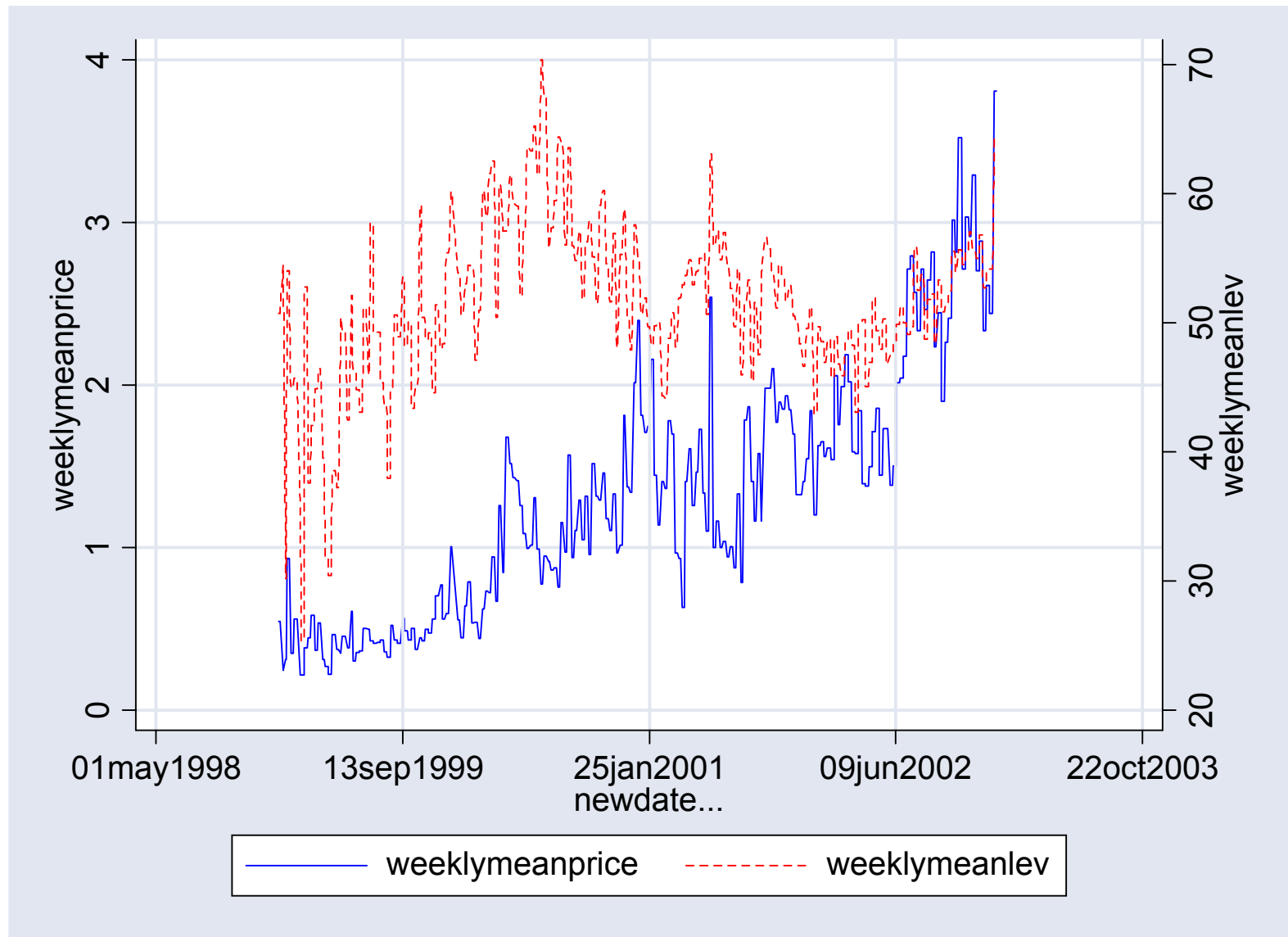

Figure 4: This figure plots CDS premia and firm leverage, both averaged across reference entities on a weekly basis. 


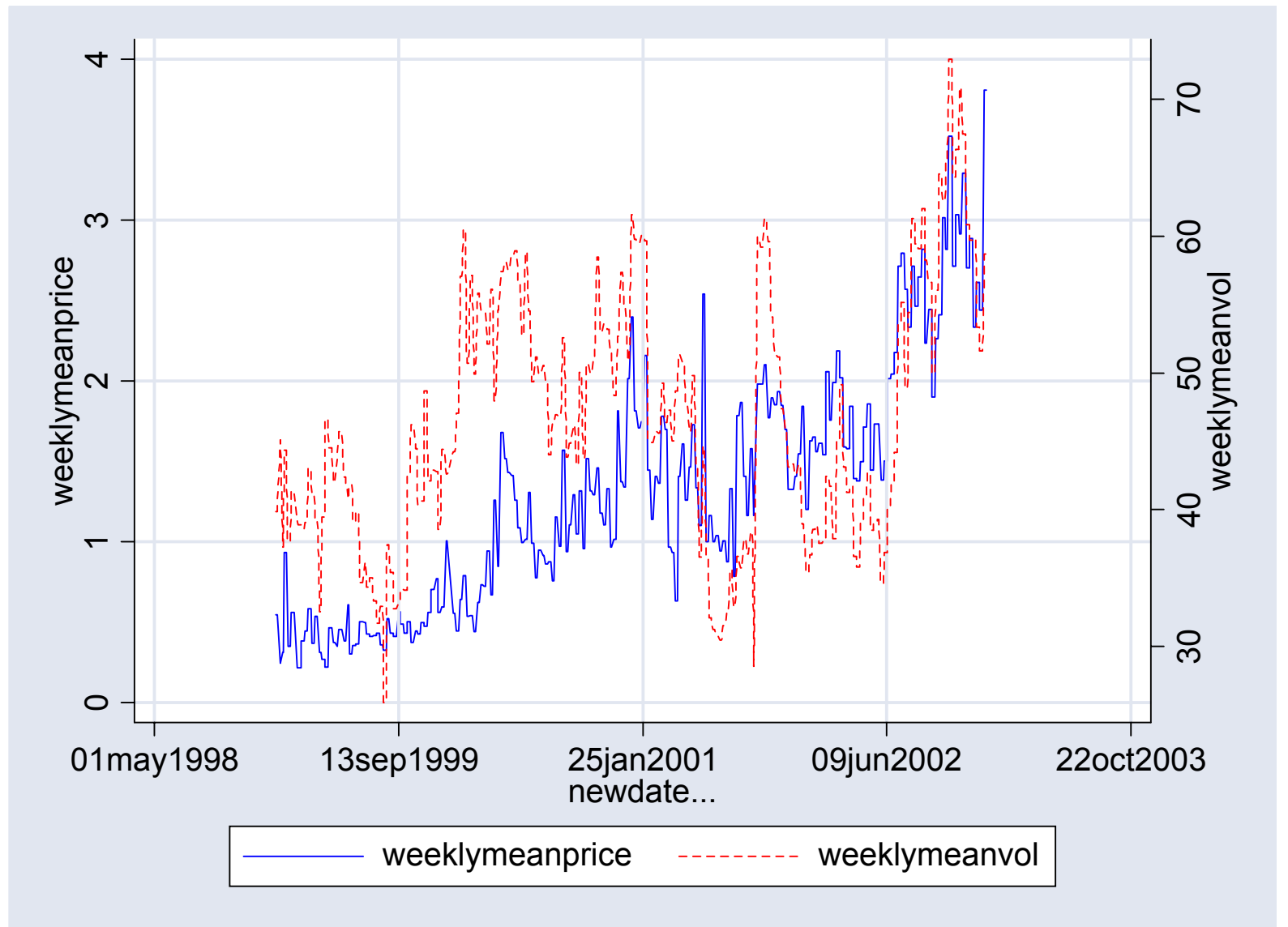

Figure 5: This figure plots CDS premia and equity volatilities, both averaged across reference entities on a weekly basis. 


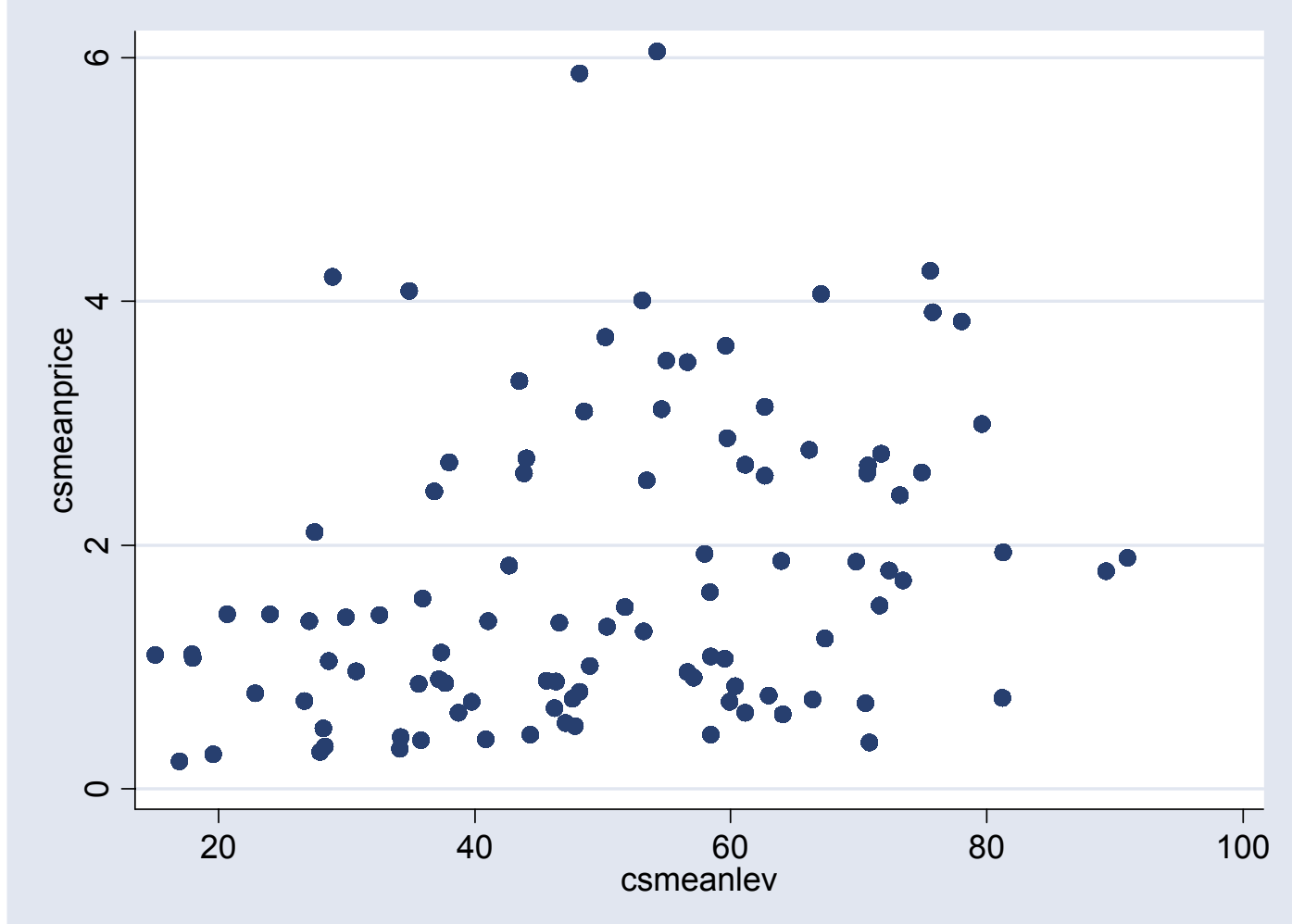

Figure 6: This figure plots the firm-specific (time-series) average of the CDS premia vs. average leverage. 


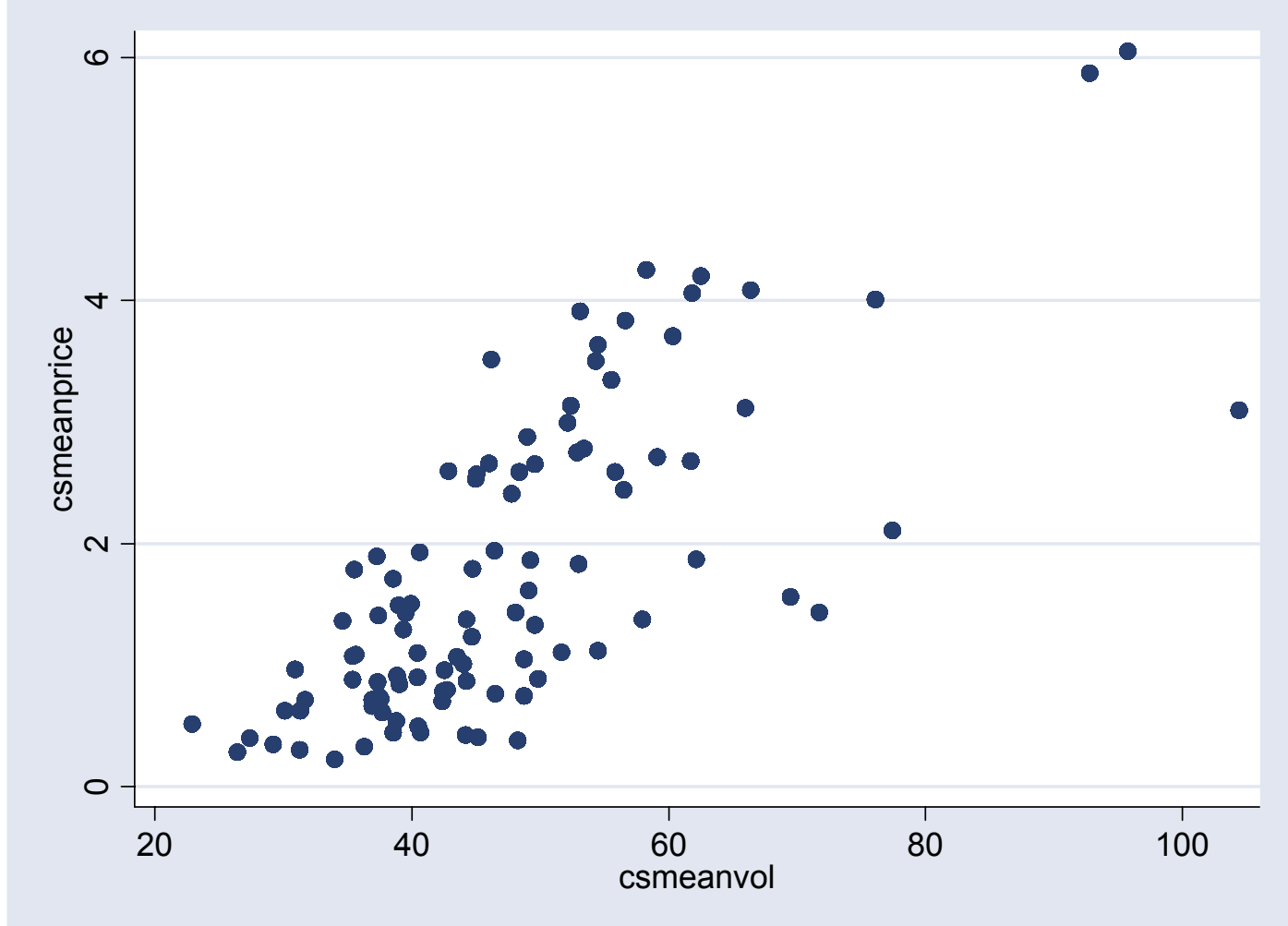

Figure 7: This figure plots the firm-specific (time series) average CDS premia vs. average equity volatility. 


\section{Appendix: Companies Used in Company-by-Company Time Series Regressions}

\begin{tabular}{|c|c|c|c|c|}
\hline \multirow[t]{2}{*}{ Issuer Names } & \multicolumn{2}{|c|}{ Differences } & \multicolumn{2}{|c|}{ Levels } \\
\hline & Bid & Offer & Bid & Offer \\
\hline ABITIBI-CONSOLIDATED INC & 1 & 0 & 1 & 0 \\
\hline ALBERTSONS INC & 1 & 1 & 1 & 1 \\
\hline ALCOA INC & 1 & 1 & 1 & 1 \\
\hline AMR CORP & 0 & 1 & 1 & 1 \\
\hline AOL TIME WARNER INC & 1 & 1 & 1 & 1 \\
\hline ARROW ELECTRONICS INC & 1 & 1 & 1 & 1 \\
\hline AT\&T WIRELESS SERVICES INC & 1 & 1 & 1 & 1 \\
\hline AUTOZONE INC & 0 & 1 & 0 & 1 \\
\hline BELLSOUTH CORPORATION & 1 & 1 & 1 & 1 \\
\hline BLACK AND DECKER CORP & 1 & 1 & 1 & 1 \\
\hline BOEING CO & 1 & 1 & 1 & 1 \\
\hline BORGWARNER INC & 0 & 1 & 0 & 1 \\
\hline BOSTON SCIENTIFIC CORP & 0 & 1 & 0 & 1 \\
\hline BURLINGTON NORTHERN SANTA FE CORP & 1 & 1 & 1 & 1 \\
\hline CAMPBELL SOUP CO & 1 & 1 & 1 & 1 \\
\hline CARNIVAL CORP & 1 & 1 & 1 & 1 \\
\hline CATERPILLAR INC & 1 & 1 & 1 & 1 \\
\hline CENDANT CORP & 1 & 1 & 1 & 1 \\
\hline CENTEX CORP & 0 & 1 & 0 & 1 \\
\hline CENTURYTEL INC & 0 & 1 & 0 & 1 \\
\hline CITIZENS COMMUNICATIONS CO. & 1 & 1 & 1 & 1 \\
\hline CLEAR CHANNEL COMMUNICATIONS INC & 1 & 1 & 1 & 1 \\
\hline COCA-COLA ENTERPRISES INC & 1 & 1 & 1 & 1 \\
\hline COMPAQ COMPUTER CORP & 1 & 1 & 1 & 1 \\
\hline COMPUTER ASSOCIATES INTERNATIONAL INC & 0 & 1 & 0 & 1 \\
\hline CONAGRA FOODS INC & 1 & 0 & 1 & 0 \\
\hline COX COMMUNICATIONS INC & 1 & 1 & 1 & 1 \\
\hline CSX CORP & 1 & 1 & 1 & 1 \\
\hline CVS CORP & 1 & 1 & 1 & 1 \\
\hline DANA CORP & 1 & 1 & 1 & 1 \\
\hline DEERE AND CO & 1 & 1 & 1 & 1 \\
\hline DELPHI AUTOMOTIVE SYSTEMS CORP & 1 & 1 & 1 & 1 \\
\hline DELTA AIRLINES INC & 0 & 1 & 1 & 1 \\
\hline DILLARDS INC & 1 & 0 & 1 & 0 \\
\hline DOW CHEMICAL CO, THE & 1 & 1 & 1 & 1 \\
\hline DUPONT DE NEMOURS CO & 0 & 1 & 0 & 1 \\
\hline EASTMAN KODAK CO & 1 & 1 & 1 & 1 \\
\hline EL PASO CORP & 1 & 1 & 1 & 1 \\
\hline ELECTRONIC DATA SYSTEMS CORP & 1 & 1 & 1 & 1 \\
\hline ENRON CORP & 1 & 1 & 1 & 1 \\
\hline FEDERAL EXPRESS CORP & 0 & 1 & 0 & 1 \\
\hline FEDERATED DEPARTMENT STORES INC & 1 & 1 & 1 & 1 \\
\hline GAP INC, THE & 1 & 1 & 1 & 1 \\
\hline GENERAL MOTORS CORP & 1 & 0 & 1 & 0 \\
\hline GEORGIA-PACIFIC CORP & 1 & 1 & 1 & 1 \\
\hline GOODRICH CORP & 1 & 1 & 1 & 1 \\
\hline GOODYEAR TIRE AND RUBBER CO, THE & 1 & 1 & 1 & 1 \\
\hline HEWLETT-PACKARD CO & 1 & 1 & 1 & 1 \\
\hline HILTON HOTELS CORP & 1 & 1 & 1 & 1 \\
\hline HJ HEINZ CO & 0 & 0 & 0 & 1 \\
\hline INGERSOLL-RAND CO & 0 & 1 & 0 & 1 \\
\hline INTERNATIONAL BUSINESS MACHINES CORP & 1 & 1 & 1 & 1 \\
\hline INTERNATIONAL PAPER CO & 1 & 1 & 1 & 1 \\
\hline INTERPUBLIC GROUP COS. INC & 1 & 1 & 1 & 1 \\
\hline JC PENNEY CO INC & 1 & 1 & 1 & 1 \\
\hline KROGER & 1 & 0 & 1 & 0 \\
\hline LENNAR CORP & 0 & 1 & 0 & 1 \\
\hline LIMITED BRANDS & 0 & 0 & 0 & 1 \\
\hline LOCKHEED MARTIN CORP & 1 & 1 & 1 & 1 \\
\hline LUCENT TECHNOLOGIES INC & 1 & 1 & 1 & 1 \\
\hline MASCO CORP & 1 & 1 & 1 & 1 \\
\hline MATTEL INC & 0 & 1 & 0 & 1 \\
\hline MAY DEPARTMENT STORES CO & 1 & 1 & 1 & 1 \\
\hline MAYTAG CORP & 1 & 1 & 1 & 1 \\
\hline MCDONALDS CORP & 1 & 1 & 1 & 1 \\
\hline MCKESSON CORP & 0 & 0 & 0 & 1 \\
\hline MGM MIRAGE INC & 1 & 1 & 1 & 1 \\
\hline MOTOROLA INC & 1 & 1 & 1 & 1 \\
\hline NEWELL RUBBERMAID INC & 1 & 1 & 1 & 1 \\
\hline
\end{tabular}


Appendix: Companies Used in Company-by-Company Time Series Regressions

\begin{tabular}{|c|c|c|c|c|}
\hline \multirow[t]{2}{*}{ Issuer Names } & \multicolumn{2}{|c|}{ Differences } & \multicolumn{2}{|c|}{ Levels } \\
\hline & Bid & Offer & Bid & Offer \\
\hline NEXTEL COMMUNICATIONS INC & 1 & 1 & 1 & 1 \\
\hline NORDSTROM INC & 1 & 1 & 1 & 1 \\
\hline NORFOLK SOUTHERN CORP & 1 & 1 & 1 & 1 \\
\hline NORTHROP GRUMMAN CORP & 0 & 1 & 0 & 1 \\
\hline OMNICOM GROUP & 1 & 1 & 1 & 1 \\
\hline PARK PLACE ENTERTAINMENT CORP & 1 & 1 & 1 & 1 \\
\hline PRIDE INTERNATIONAL INC & 0 & 0 & 1 & 0 \\
\hline PROCTER AND GAMBLE CO, THE & 0 & 1 & 0 & 1 \\
\hline ROYAL CARIBBEAN CRUISES LTD & 1 & 0 & 1 & 1 \\
\hline RYDER SYSTEM INC & 0 & 1 & 0 & 1 \\
\hline SBC COMMUNICATIONS INC & 1 & 1 & 1 & 1 \\
\hline SEARS ROEBUCK AND CO & 1 & 1 & 1 & 1 \\
\hline SOLECTRON CORP & 1 & 1 & 1 & 1 \\
\hline SOUTHWEST AIRLINES CO & 1 & 1 & 1 & 1 \\
\hline SPRINT CORP & 1 & 1 & 1 & 1 \\
\hline SUN MICROSYSTEMS INC & 1 & 1 & 1 & 1 \\
\hline TARGET CORP & 1 & 1 & 1 & 1 \\
\hline TENET HEALTHCARE CORP & 1 & 0 & 1 & 0 \\
\hline TJX COMPANIES INC & 0 & 1 & 0 & 1 \\
\hline TOYS R US INC & 1 & 1 & 1 & 1 \\
\hline TRIBUNE CO & 0 & 1 & 0 & 1 \\
\hline TRW INC & 1 & 1 & 1 & 1 \\
\hline TYCO INTERNATIONAL LTD & 1 & 1 & 1 & 1 \\
\hline VIACOM INC & 1 & 1 & 1 & 1 \\
\hline VISTEON CORP & 1 & 1 & 1 & 1 \\
\hline WAL-MART STORES INC & 1 & 1 & 1 & 1 \\
\hline WALT DISNEY CO, THE & 1 & 1 & 1 & 1 \\
\hline WEYERHAEUSER CO & 0 & 1 & 0 & 1 \\
\hline WHIRLPOOL CORP & 1 & 1 & 1 & 1 \\
\hline WILLIAMS COMPANIES INC & 1 & 1 & 1 & 1 \\
\hline WYETH (AMERICAN HOME PRODUCTS CORP) & 1 & 1 & 1 & 1 \\
\hline XEROX CORP & 1 & 1 & 1 & 1 \\
\hline
\end{tabular}


Table 1

\section{Summary statistics}

This table presents descriptive statistics for the regression variables. It also includes numerical S\&P and Moody's credit ratings. Numerical ratings in the sample range from 1 (Aaa) to 20 (Ca) for Moody's and from 1 (AAA) to 25 (in default) for S\&P.

\begin{tabular}{|c|c|c|c|c|c|c|}
\hline & \multirow[t]{2}{*}{ mean } & \multirow[t]{2}{*}{ stdev. } & \multirow[t]{2}{*}{ 5th percentile } & \multirow[t]{2}{*}{ 95th percentile } & \multicolumn{2}{|c|}{ Correlation with CDS premium } \\
\hline & & & & & Time series & Cross-sectional \\
\hline CDS premium (\%) & 1.80 & 1.73 & 0.28 & 5.30 & & \\
\hline Leverage (\%) & 51.57 & 17.71 & 22.75 & 79.85 & 0.28 & 0.23 \\
\hline Volatility (\%) & 48.80 & 20.39 & 25.46 & 84.09 & 0.65 & 0.70 \\
\hline 10 year yield (\%) & 4.92 & 0.66 & 3.85 & 6.11 & -0.69 & \\
\hline S\&P Rating & 7.9 & 2.1 & 4 & 11 & & \\
\hline Moody's Rating & 8.1 & 2.2 & 4 & 11 & & \\
\hline Slope (\%) & 1.45 & 0.82 & -0.51 & 2.37 & 0.59 & \\
\hline 2 year yield (\%) & 3.47 & 1.39 & 1.80 & 6.33 & -0.68 & \\
\hline S\&P 500 & $1,111.84$ & 180.87 & 847.76 & $1,436.51$ & -0.70 & \\
\hline Smirk slope (\%) & 0.59 & 0.07 & 0.49 & 0.70 & -0.20 & \\
\hline VIX (\%) & 29.60 & 7.19 & 21.11 & 43.86 & 0.52 & \\
\hline
\end{tabular}


Table 2

Regression Using Variables Suggested by Theory

This table presents descriptive statistics and regression results for linear regressions using the three explanatory variables suggested by theory: leverage, volatility and the riskless interest rate. Reported coefficients are averages for regression coefficients from timeseries regressions using all observations on a given underlying company. T-statistics are computed based on the time-series regression coefficients as in Collin-Dufresne, Goldstein and Martin (2001).

\begin{tabular}{|c|c|c|c|c|c|c|c|c|c|c|c|c|}
\hline & \multicolumn{6}{|c|}{ Regressions in Differences } & \multicolumn{6}{|c|}{ Regressions in Levels } \\
\hline & \multicolumn{3}{|c|}{ Bid Quotes } & \multicolumn{3}{|c|}{ Offer Quotes } & \multicolumn{3}{|c|}{ Bid Quotes } & \multicolumn{3}{|c|}{ Offer Quotes } \\
\hline & $\begin{array}{l}\text { Low } \\
\text { Rating }\end{array}$ & $\begin{array}{c}\text { High } \\
\text { Rating }\end{array}$ & All & $\begin{array}{c}\text { Low } \\
\text { Rating }\end{array}$ & $\begin{array}{l}\text { High } \\
\text { Rating }\end{array}$ & All & $\begin{array}{c}\text { Low } \\
\text { Rating }\end{array}$ & $\begin{array}{c}\text { High } \\
\text { Rating }\end{array}$ & All & $\begin{array}{c}\text { Low } \\
\text { Rating }\end{array}$ & $\begin{array}{l}\text { High } \\
\text { Rating }\end{array}$ & All \\
\hline Coefficients & 0.007 & 0.003 & 0.005 & 0.019 & 0.000 & 0.010 & 0.104 & -1.072 & -0.492 & -2.242 & -0.783 & -1.513 \\
\hline Leverage & 0.072 & 0.041 & 0.056 & 0.060 & 0.035 & 0.048 & 0.076 & 0.051 & 0.063 & 0.100 & 0.046 & 0.073 \\
\hline Equity Volatility & 0.011 & 0.004 & 0.008 & 0.023 & 0.006 & 0.014 & 0.017 & 0.004 & 0.010 & 0.023 & 0.007 & 0.015 \\
\hline 10-Year Yield & -0.307 & -0.118 & -0.212 & -0.387 & -0.169 & -0.278 & -0.596 & -0.100 & -0.345 & -0.342 & -0.057 & -0.200 \\
\hline Constant & 0.87 & 0.64 & 1.09 & 1.56 & 0.04 & 1.47 & 0.09 & -1.81 & -0.78 & -1.66 & -1.62 & -2.11 \\
\hline Leverage & 6.00 & 4.82 & 7.52 & 4.97 & 4.85 & 6.66 & 5.48 & 5.86 & 7.72 & 6.30 & 5.69 & 7.87 \\
\hline Equity Volatility & 4.58 & 2.97 & 5.24 & 5.19 & 3.61 & 5.72 & 3.64 & 1.97 & 3.99 & 3.56 & 3.39 & 4.34 \\
\hline 10-Year Yield & -4.49 & -2.49 & -4.97 & -3.13 & -2.35 & -3.86 & -4.27 & -1.29 & -4.13 & -2.28 & -0.74 & -2.35 \\
\hline $\mathrm{R}^{2}$ & $23.3 \%$ & $21.3 \%$ & $22.3 \%$ & $24.2 \%$ & $23.3 \%$ & $23.7 \%$ & $65.5 \%$ & $57.3 \%$ & $61.4 \%$ & $59.6 \%$ & $52.6 \%$ & $56.1 \%$ \\
\hline N. of Companies & 39 & 39 & 78 & 45 & 45 & 90 & 40 & 41 & 81 & 47 & 47 & 94 \\
\hline Avg. N. of Observ. & 60.0 & 59.5 & 59.7 & 55.6 & 61.0 & 58.3 & 58.3 & 60.5 & 59.4 & 55.2 & 60.4 & 57.8 \\
\hline Avg. Day Btw. Quotes & 19.7 & 19.6 & 19.7 & 20.1 & 19.1 & 19.6 & 20.9 & 19.3 & 20.1 & 20.5 & 19.6 & 20.1 \\
\hline
\end{tabular}


Table 3

\section{Regression Using Leverage Only}

This table presents descriptive statistics and regression results for linear regressions using one of the explanatory variables suggested by theory, leverage. Reported coefficients are averages for regression coefficients from time-series regressions using all observations on a given underlying company. T-statistics are computed based on the time-series regression coefficients as in Collin-Dufresne, Goldstein and Martin (2001).

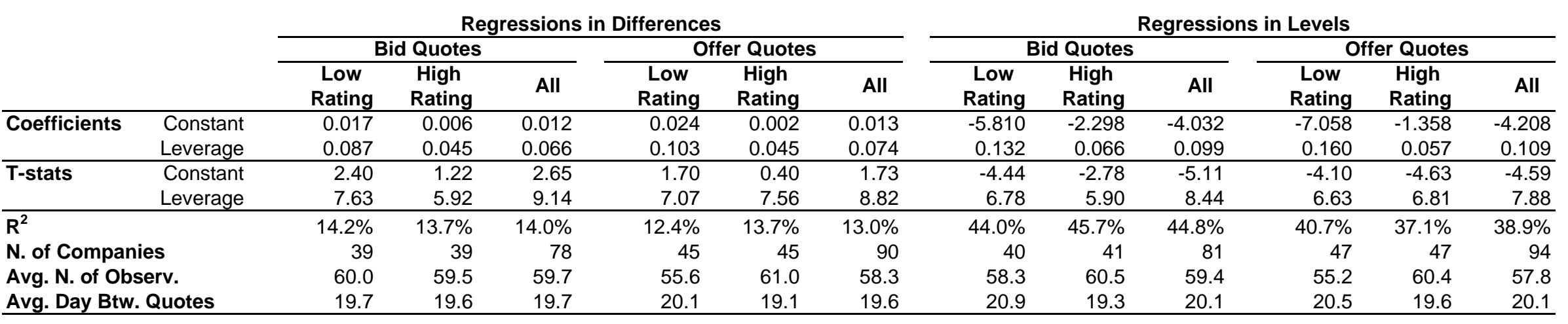




\section{Table 4}

\section{Regression Using Equity Volatility Only}

This table presents descriptive statistics and regression results for linear regressions using one of the explanatory variables suggested by theory, equity volatility. Reported coefficients are averages for regression coefficients from time-series regressions using all observations on a given underlying company. T-statistics are computed based on the time-series regression coefficients as in Collin-Dufresne, Goldstein and Martin (2001).

\begin{tabular}{|c|c|c|c|c|c|c|c|c|c|c|c|c|}
\hline & \multicolumn{6}{|c|}{ Regressions in Differences } & \multicolumn{6}{|c|}{ Regressions in Levels } \\
\hline & \multicolumn{3}{|c|}{ Bid Quotes } & \multicolumn{3}{|c|}{ Offer Quotes } & \multicolumn{3}{|c|}{ Bid Quotes } & \multicolumn{3}{|c|}{ Offer Quotes } \\
\hline & $\begin{array}{c}\text { Low } \\
\text { Rating }\end{array}$ & $\begin{array}{c}\text { High } \\
\text { Rating }\end{array}$ & All & $\begin{array}{c}\text { Low } \\
\text { Rating }\end{array}$ & $\begin{array}{c}\text { High } \\
\text { Rating }\end{array}$ & All & $\begin{array}{c}\text { Low } \\
\text { Rating }\end{array}$ & $\begin{array}{c}\text { High } \\
\text { Rating }\end{array}$ & All & $\begin{array}{c}\text { Low } \\
\text { Rating }\end{array}$ & $\begin{array}{c}\text { High } \\
\text { Rating }\end{array}$ & All \\
\hline Coefficients $\quad$ Constant & 0.041 & 0.018 & 0.030 & 0.052 & 0.015 & 0.033 & 0.356 & 0.120 & 0.237 & 0.705 & 0.156 & 0.430 \\
\hline Equity Volatility & 0.016 & 0.007 & 0.011 & 0.027 & 0.010 & 0.018 & 0.038 & 0.016 & 0.027 & 0.037 & 0.017 & 0.027 \\
\hline Constant & 5.59 & 2.47 & 5.57 & 3.63 & 1.92 & 4.01 & 0.92 & 1.02 & 1.19 & 1.60 & 0.95 & 1.83 \\
\hline Equity Volatility & 6.25 & 5.25 & 7.62 & 6.00 & 4.94 & 7.00 & 5.25 & 5.01 & 6.62 & 4.40 & 4.73 & 5.82 \\
\hline $\mathbf{R}^{2}$ & $10.1 \%$ & $6.9 \%$ & $8.5 \%$ & $14.4 \%$ & $11.0 \%$ & $12.7 \%$ & $29.7 \%$ & $24.3 \%$ & $27.0 \%$ & $26.9 \%$ & $23.9 \%$ & $25.4 \%$ \\
\hline N. of Companies & 39 & 39 & 78 & 45 & 45 & 90 & 40 & 41 & 81 & 47 & 47 & 94 \\
\hline Avg. N. of Observ. & 60.0 & 59.5 & 59.7 & 55.6 & 61.0 & 58.3 & 58.3 & 60.5 & 59.4 & 55.2 & 60.4 & 57.8 \\
\hline Avg. Day Btw. Quotes & 19.7 & 19.6 & 19.7 & 20.1 & 19.1 & 19.6 & 20.9 & 19.3 & 20.1 & 20.5 & 19.6 & 20.1 \\
\hline
\end{tabular}




\section{Table 5}

\section{Regression Using 10-Year US Treasury Bond Yields Only}

This table presents descriptive statistics and regression results for linear regressions using one of the explanatory variables suggested by theory, the riskless interest rate. Reported coefficients are averages for regression coefficients from time-series regressions using all observations on a given underlying company. T-statistics are computed based on the time-series regression coefficients as in Collin-Dufresne, Goldstein and Martin (2001).

\begin{tabular}{|c|c|c|c|c|c|c|c|c|c|c|c|c|}
\hline & \multicolumn{6}{|c|}{ Regressions in Differences } & \multicolumn{6}{|c|}{ Regressions in Levels } \\
\hline & \multicolumn{3}{|c|}{ Bid Quotes } & \multicolumn{3}{|c|}{ Offer Quotes } & \multicolumn{3}{|c|}{ Bid Quotes } & \multicolumn{3}{|c|}{ Offer Quotes } \\
\hline & $\begin{array}{l}\text { Low } \\
\text { Rating }\end{array}$ & $\begin{array}{l}\text { High } \\
\text { Rating }\end{array}$ & All & $\begin{array}{l}\text { Low } \\
\text { Rating }\end{array}$ & $\begin{array}{l}\text { High } \\
\text { Rating }\end{array}$ & All & $\begin{array}{c}\text { Low } \\
\text { Rating }\end{array}$ & $\begin{array}{l}\text { High } \\
\text { Rating }\end{array}$ & All & $\begin{array}{l}\text { Low } \\
\text { Rating }\end{array}$ & $\begin{array}{c}\text { High } \\
\text { Rating }\end{array}$ & All \\
\hline Coefficients & 0.030 & 0.014 & 0.022 & 0.036 & 0.010 & 0.023 & 8.848 & 3.943 & 6.365 & 8.608 & 3.591 & 6.099 \\
\hline $\begin{array}{c}10-Y e a r \text { Yield } \\
\end{array}$ & -0.486 & -0.285 & -0.386 & -0.661 & -0.356 & -0.509 & -1.306 & -0.596 & -0.947 & -1.192 & -0.500 & -0.846 \\
\hline Constant & 5.20 & 1.99 & 4.77 & 2.60 & 1.35 & 2.90 & 9.12 & 5.17 & 9.50 & 6.81 & 5.32 & 8.04 \\
\hline 10-Year Yield & -5.53 & -5.79 & -7.51 & -5.03 & -4.63 & -6.57 & -7.86 & -4.57 & -8.46 & -5.38 & -4.24 & -6.52 \\
\hline$\overline{\mathbf{R}^{2}}$ & $6.3 \%$ & $7.5 \%$ & $6.9 \%$ & $4.7 \%$ & $7.9 \%$ & $6.3 \%$ & $40.1 \%$ & $32.6 \%$ & $36.3 \%$ & $28.4 \%$ & $27.9 \%$ & $28.2 \%$ \\
\hline N. of Companies & 39 & 39 & 78 & 45 & 45 & 90 & 40 & 41 & 81 & 47 & 47 & 94 \\
\hline Avg. N. of Observ. & 60.0 & 59.5 & 59.7 & 55.6 & 61.0 & 58.3 & 58.3 & 60.5 & 59.4 & 55.2 & 60.4 & 57.8 \\
\hline Avg. Day Btw. Quotes & 19.7 & 19.6 & 19.7 & 20.1 & 19.1 & 19.6 & 20.9 & 19.3 & 20.1 & 20.5 & 19.6 & 20.1 \\
\hline
\end{tabular}


Table 6

Regression Using the Regressors from Collin-Dufresne, Goldstein and Martin (2001)

This table presents descriptive statistics and regression results for linear regressions using the benchmark specification in Collin-Dufresne, Goldstein and Martin (2001). Reported coefficients are averages for regression coefficients from time-series regressions using all observations on a given underlying company. T-statistics are computed based on the time-series regression coefficients as in Collin-Dufresne, Goldstein and Martin (2001).

\begin{tabular}{|c|c|c|c|c|c|c|c|c|c|c|c|c|}
\hline & \multicolumn{6}{|c|}{ Regressions in Differences } & \multicolumn{6}{|c|}{ Regressions in Levels } \\
\hline & \multicolumn{3}{|c|}{ Bid Quotes } & \multicolumn{3}{|c|}{ Offer Quotes } & \multicolumn{3}{|c|}{ Bid Quotes } & \multicolumn{3}{|c|}{ Offer Quotes } \\
\hline & $\begin{array}{c}\text { Low } \\
\text { Rating }\end{array}$ & $\begin{array}{l}\text { High } \\
\text { Rating }\end{array}$ & All & $\begin{array}{c}\text { Low } \\
\text { Rating }\end{array}$ & $\begin{array}{l}\text { High } \\
\text { Rating }\end{array}$ & All & $\begin{array}{c}\text { Low } \\
\text { Rating }\end{array}$ & $\begin{array}{l}\text { High } \\
\text { Rating }\end{array}$ & All & $\begin{array}{c}\text { Low } \\
\text { Rating }\end{array}$ & $\begin{array}{l}\text { High } \\
\text { Rating }\end{array}$ & All \\
\hline Coefficients & 0.014 & 0.010 & 0.012 & -0.002 & -0.007 & -0.004 & 12.046 & 2.678 & 7.304 & 6.201 & 2.771 & 4.486 \\
\hline Leverage & 0.063 & 0.033 & 0.048 & 0.059 & 0.033 & 0.046 & 0.075 & 0.033 & 0.054 & 0.073 & 0.034 & 0.054 \\
\hline Equilty Volatility & 0.010 & 0.004 & 0.007 & 0.020 & 0.006 & 0.013 & 0.018 & 0.005 & 0.012 & 0.022 & 0.007 & 0.015 \\
\hline 2-Year Yield & -0.115 & -0.121 & -0.118 & -0.256 & -0.143 & -0.200 & -1.051 & -0.209 & -0.625 & -0.348 & -0.340 & -0.344 \\
\hline Yield Curve Slope & 0.005 & -0.116 & -0.055 & 0.003 & -0.104 & -0.050 & -0.051 & -0.077 & -0.064 & 0.150 & -0.020 & 0.065 \\
\hline S\&P 500 & -1.924 & -0.284 & -1.104 & -1.301 & -0.034 & -0.667 & -1.851 & -0.411 & -1.122 & -1.150 & -0.453 & -0.802 \\
\hline Smirk Slope & 0.144 & -0.150 & -0.003 & -0.524 & 0.148 & -0.188 & 0.904 & 0.364 & 0.631 & 0.613 & 0.862 & 0.738 \\
\hline Sq. 10-Year Yield & -0.115 & -0.117 & -0.116 & 0.009 & 0.076 & 0.042 & 0.114 & 0.016 & 0.064 & 0.013 & 0.049 & 0.031 \\
\hline $\begin{array}{ll}\text { T-stats } & \text { Constant }\end{array}$ & 1.12 & 1.61 & 1.74 & -0.18 & -2.23 & -0.74 & 1.64 & 1.11 & 1.90 & 0.96 & 1.05 & 1.30 \\
\hline Leverage & 5.28 & 3.48 & 6.18 & 4.22 & 4.87 & 5.88 & 4.79 & 4.50 & 6.09 & 4.64 & 5.55 & 6.21 \\
\hline Equilty Volatility & 4.28 & 2.48 & 4.81 & 4.79 & 3.54 & 5.48 & 3.81 & 2.47 & 4.36 & 4.62 & 3.80 & 5.51 \\
\hline 2-Year Yield & -0.99 & -2.88 & -1.93 & -1.79 & -3.35 & -2.67 & -1.37 & -1.35 & -1.62 & -0.50 & -1.59 & -0.95 \\
\hline Yield Curve Slope & 0.03 & -1.57 & -0.61 & 0.02 & -1.21 & -0.49 & -0.18 & -0.84 & -0.43 & 0.61 & -0.20 & 0.48 \\
\hline S\&P 500 & -2.72 & -0.90 & -2.79 & -1.34 & -0.15 & -1.33 & -1.47 & -1.11 & -1.72 & -1.10 & -1.08 & -1.42 \\
\hline Smirk Slope & 0.26 & -0.97 & -0.01 & -1.04 & 0.66 & -0.68 & 1.07 & 1.02 & 1.39 & 0.76 & 2.29 & 1.66 \\
\hline Sq. 10-Year Yield & -0.66 & -1.48 & -1.23 & 0.04 & 1.47 & 0.39 & 1.59 & 0.64 & 1.71 & 0.19 & 1.46 & 0.84 \\
\hline$\overline{R^{2}}$ & $31.1 \%$ & $27.9 \%$ & $29.5 \%$ & $34.1 \%$ & $30.5 \%$ & $32.3 \%$ & $76.1 \%$ & $70.6 \%$ & $73.3 \%$ & $75.6 \%$ & $68.6 \%$ & $72.1 \%$ \\
\hline Number of Companies & 39 & 39 & 78 & 45 & 45 & 90 & 40 & 41 & 81 & 47 & 47 & 94 \\
\hline Avg. Number of Observ. & 60.0 & 59.4 & 59.7 & 55.6 & 61.0 & 58.3 & 58.3 & 60.4 & 59.4 & 55.2 & 60.4 & 57.8 \\
\hline Avg. Days Btw. Quotes & 19.7 & 19.6 & 19.7 & 20.1 & 19.1 & 19.6 & 20.9 & 19.3 & 20.1 & 20.5 & 19.6 & 20.1 \\
\hline
\end{tabular}


Table 7

Panel regressions - offer quotes

This table reports our findings for panel versions of regression (1) and the three univariate regressions (2)-(4). Panel A reports results for OLS regressions with

Huber/White/Sandwich variance estimates. Panels B \& C report results for regressions with fixed effects and quarter dummies, respectively. The panel contains 5436 offer quotes for 94 different reference entities with at least 25 quotes each.

Panel A

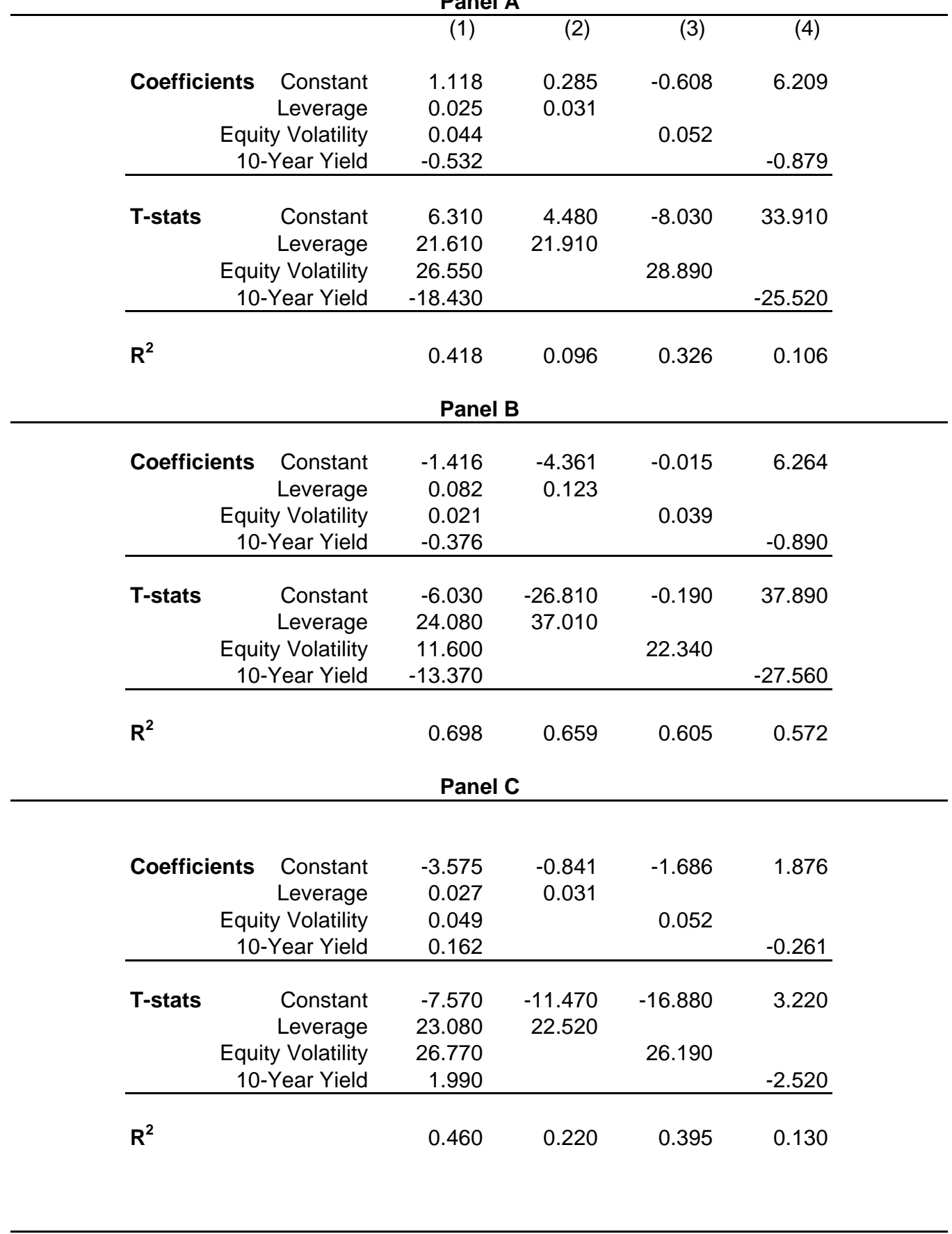


Table 8

Panel regressions - bid quotes

This table reports our findings for panel versions of regression (1) and the three univariate regressions (2)-(4). Panel A reports results for simple OLS regressions with Huber/White/Sandwich variance estimates. Panels B \& C report results for regressions with fixed effects and quarter dummies, respectively. The panel contains 4813 bid quotes for 81 different reference entities with at least 25 quotes each.

Panel A

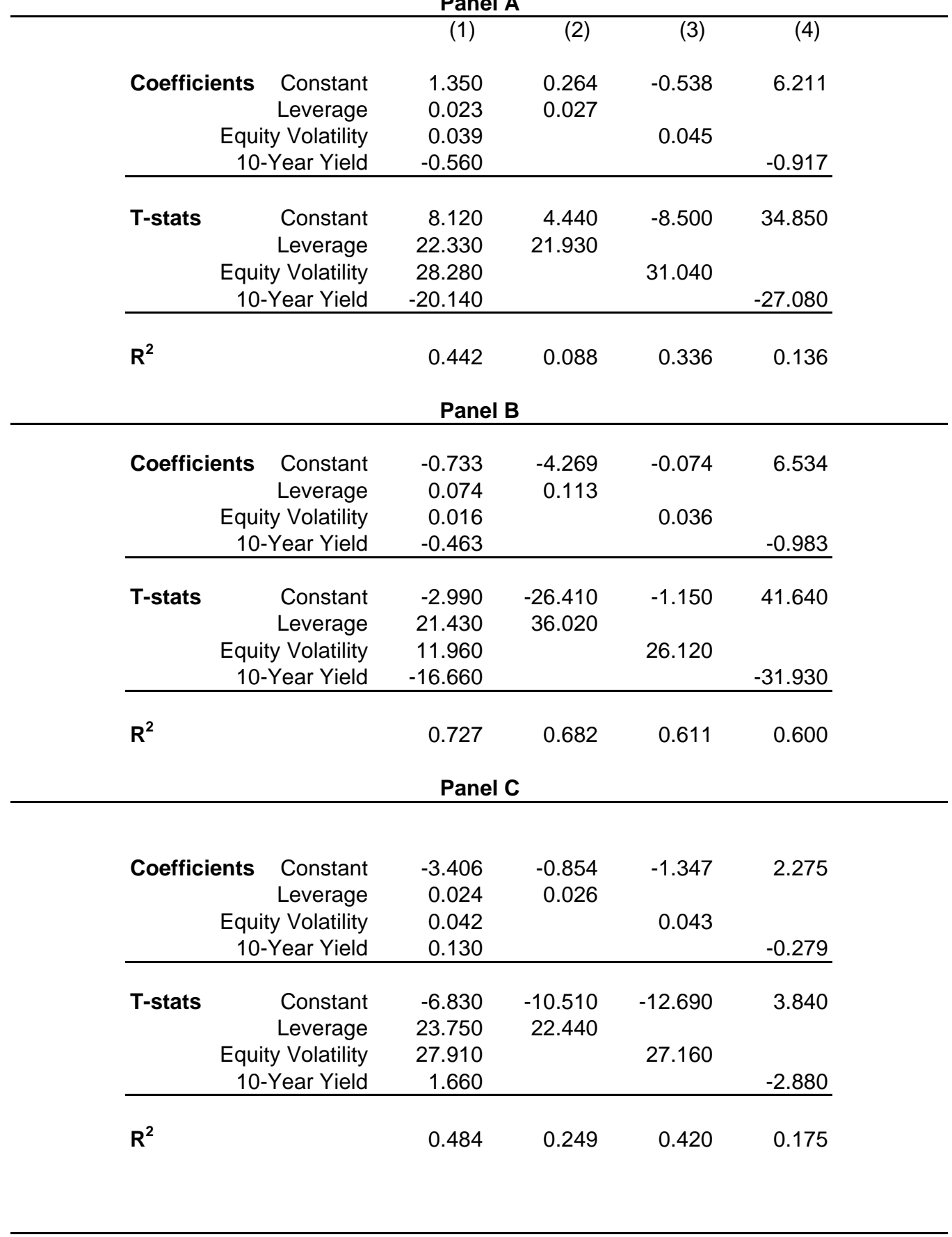


Table 9

Principal Component Analysis for Levels using Data on 15 Companies

This table presents results of a principal component analysis using data on the 15 most quoted companies. Principal components is applied either to the levels of the CDS premia or the errors from regression (1) explaining the levels of CDS premia. For each exercise the first two vectors and the percentage of the variance explained by each factor are reported.

Panel A: Bid Levels

\begin{tabular}{|rrrr|}
\hline \multicolumn{2}{|c|}{ Regression errors } & \multicolumn{2}{c|}{ Premia } \\
\hline First Component & Second Component & First Component & Second Component \\
\hline 0.27 & -0.15 & 0.30 & -0.01 \\
0.39 & -0.01 & 0.32 & 0.09 \\
-0.02 & -0.49 & 0.15 & -0.38 \\
0.34 & 0.27 & 0.31 & 0.15 \\
0.32 & 0.03 & 0.27 & 0.24 \\
0.20 & -0.08 & 0.25 & -0.27 \\
0.04 & -0.47 & -0.03 & -0.51 \\
0.33 & -0.01 & 0.31 & 0.04 \\
0.00 & -0.40 & -0.03 & -0.36 \\
0.39 & 0.07 & 0.27 & 0.05 \\
0.29 & -0.12 & 0.32 & 0.15 \\
0.23 & -0.31 & 0.23 & -0.33 \\
0.33 & 0.18 & 0.32 & -0.04 \\
0.05 & -0.34 & 0.17 & -0.38 \\
0.08 & 0.09 & 0.31 & 0.15 \\
\hline Explained by PC: & & & \\
$32.5 \%$ & $21.6 \%$ & $58.7 \%$ & $20.3 \%$ \\
\hline
\end{tabular}

Panel B: Offer Levels

\begin{tabular}{|rrrr|}
\hline \multicolumn{2}{|c|}{ Regression errors } & \multicolumn{2}{c|}{ Premia } \\
\hline First Component & Second Component & First Component & Second Component \\
\hline 0.33 & -0.08 & 0.32 & -0.09 \\
0.29 & -0.26 & 0.17 & 0.36 \\
0.04 & -0.44 & 0.20 & 0.34 \\
0.21 & -0.12 & 0.32 & 0.03 \\
0.37 & 0.05 & 0.32 & -0.08 \\
0.33 & 0.30 & 0.31 & -0.12 \\
0.35 & 0.06 & 0.30 & -0.18 \\
0.27 & -0.03 & 0.33 & -0.14 \\
0.02 & -0.39 & -0.08 & 0.34 \\
0.19 & -0.28 & 0.20 & 0.37 \\
0.05 & -0.47 & -0.03 & 0.48 \\
0.35 & 0.13 & 0.28 & -0.09 \\
-0.13 & 0.00 & 0.27 & -0.16 \\
-0.05 & -0.37 & 0.17 & 0.39 \\
0.38 & 0.10 & 0.32 & 0.07 \\
\hline Explained by PC: & & & \\
$31.0 \%$ & $25.1 \%$ & $55.1 \%$ & $24.2 \%$ \\
\hline
\end{tabular}




\section{Table 10}

\section{Principal Component Analysis for Differences using Data on 15 Companies}

This table presents results of a principal component analysis using data on the 15 most quoted companies. Principal components is applied either to the differences of the CDS premia or the errors from regression (5) explaining the differences of CDS premia. For each exercise the first two vectors and the percentage of the variance explained by each factor are reported.

\section{Panel A: Bid Differences}

\begin{tabular}{|rrrr|}
\hline \multicolumn{2}{|c|}{ Regression errors } & \multicolumn{2}{c|}{ Premia } \\
\hline First Component & Second Component & First Component & Second Component \\
\hline-0.47 & 0.19 & 0.12 & 0.53 \\
0.41 & -0.14 & 0.17 & -0.50 \\
-0.18 & 0.35 & 0.11 & 0.07 \\
0.15 & 0.42 & 0.22 & 0.07 \\
-0.17 & -0.52 & 0.33 & -0.08 \\
-0.32 & -0.16 & 0.18 & 0.43 \\
-0.06 & -0.18 & 0.35 & -0.06 \\
-0.37 & -0.09 & 0.30 & 0.13 \\
0.17 & -0.37 & 0.32 & -0.23 \\
-0.27 & -0.04 & 0.33 & 0.17 \\
0.04 & -0.39 & 0.27 & -0.05 \\
-0.12 & -0.07 & 0.28 & 0.25 \\
-0.31 & -0.11 & 0.30 & -0.23 \\
-0.19 & 0.07 & 0.21 & -0.21 \\
0.19 & 0.01 & 0.22 & 0.00 \\
\hline $24.5 \%$ & & & \\
Explained by PC: & $19.8 \%$ & $50.2 \%$ & $18.4 \%$ \\
\hline
\end{tabular}

Panel B: Offer Differences

\begin{tabular}{|rrrr|}
\hline \multicolumn{2}{|c|}{ Regression errors } & \multicolumn{2}{c|}{ Premia } \\
\hline First Component & Second Component & First Component & Second Component \\
\hline 0.41 & 0.03 & 0.28 & -0.36 \\
0.45 & -0.04 & 0.30 & -0.32 \\
0.43 & 0.04 & 0.32 & -0.24 \\
0.36 & -0.33 & 0.33 & -0.08 \\
0.04 & 0.48 & 0.26 & 0.28 \\
0.18 & 0.10 & 0.18 & 0.07 \\
0.37 & -0.07 & 0.19 & -0.30 \\
0.23 & -0.06 & 0.30 & 0.22 \\
0.17 & 0.26 & 0.31 & 0.25 \\
0.06 & 0.51 & 0.25 & 0.43 \\
-0.09 & 0.28 & 0.27 & -0.04 \\
0.14 & 0.03 & 0.21 & 0.24 \\
0.06 & 0.13 & 0.02 & -0.04 \\
0.08 & -0.04 & 0.25 & -0.31 \\
0.11 & 0.45 & 0.21 & 0.29 \\
\hline Explained by PC: & & & \\
$30.8 \%$ & $19.1 \%$ & $56.5 \%$ & $15.5 \%$ \\
\hline
\end{tabular}


Table 11

Principal Component Analysis for Levels using Data in Leverage Bins

This table presents results of a principal component analysis using data on all companies grouped in five leverage bins. Principal components is applied either to the levels of the CDS premia or the errors from regression (1) on the levels of CDS premia. For each exercise the first two vectors and the percentage of the variance explained by each factor are reported.

\section{Panel A: Bid Levels}

\begin{tabular}{|c|c|c|c|c|c|c|}
\hline \multicolumn{3}{|c|}{ Leverage (\%) } & \multicolumn{2}{|c|}{ Regressions errors } & \multicolumn{2}{|c|}{ Premia } \\
\hline Quintile & From & To & First Component & Second Component & First Component & Second Component \\
\hline $1 \mathrm{st}$ & 17.3 & $\overline{36.8}$ & 0.41 & -0.08 & 0.46 & 0.19 \\
\hline 2nd & 36.8 & 47.8 & 0.48 & -0.25 & 0.48 & 0.05 \\
\hline 3rd & 47.8 & 59.6 & 0.33 & -0.60 & 0.27 & -0.96 \\
\hline 4th & 59.6 & 70.1 & 0.61 & 0.13 & 0.49 & 0.17 \\
\hline \multirow[t]{2}{*}{ 5th } & 70.1 & 91.0 & 0.36 & 0.74 & 0.49 & 0.13 \\
\hline & & & $\begin{array}{r}\text { Explained by PC: } \\
35.6 \%\end{array}$ & $20.8 \%$ & $68.6 \%$ & $16.2 \%$ \\
\hline
\end{tabular}

Panel B: Offer Levels

\begin{tabular}{|c|c|c|c|c|c|c|}
\hline \multicolumn{3}{|c|}{ Leverage (\%) } & \multicolumn{2}{|c|}{ Regression errors } & \multicolumn{2}{|c|}{ Premia } \\
\hline Quintile & From & To & First Component & Second Component & First Component & Second Component \\
\hline $1 \mathrm{st}$ & 15.1 & 34.0 & 0.24 & 0.77 & 0.39 & -0.65 \\
\hline 2nd & 34.0 & 44.4 & 0.39 & -0.62 & 0.47 & -0.11 \\
\hline $3 r d$ & 44.4 & 55.5 & 0.39 & -0.09 & 0.39 & 0.70 \\
\hline 4th & 55.5 & 65.8 & 0.60 & 0.10 & 0.49 & 0.21 \\
\hline \multirow[t]{2}{*}{ 5th } & 65.8 & 81.4 & 0.52 & 0.06 & 0.49 & -0.15 \\
\hline & & & $\begin{array}{r}\text { Explained by PC: } \\
36.4 \%\end{array}$ & $24.0 \%$ & $66.1 \%$ & $13.2 \%$ \\
\hline
\end{tabular}

